\title{
Macera Rekreasyonu Katılımcılarının Risk Alma Davranışlarında Farklııı Yaratan Değişkenlerin İncelenmesi
}

\section{Cem Surrı DİNÇ${ }^{1}$, Özge YAVAŞ TEZ ${ }^{2}$}

\begin{tabular}{lr}
\hline Özet & Anahtar Kelimeler \\
\hline Amaç: Bu çalışmanın amacı, macera rekreasyonu katılımcılarının risk alma davranışlarında & Macera Rekreasyonu, \\
farklılık yaratan değisenlerin incelenmesidir. & Risk Alma, \\
Materyal ve Metot: Çalışmaya hava, kara ve su tabanlı on iki farklı etkinlikten 652 macera & DOSPERT.
\end{tabular}
sporcusu (158 kadın; $\bar{x}=34,59, \mathrm{SS}=9,93$ yıl; 494 erkek; $\bar{x}=34,69, S S=9,41$ yıl) katılmıstır. Veriler kişisel bilgi formu ve Alana Özgü Risk Alma Ölçeği (DOSPERT) kullanılarak toplanmıștır. Hipotez testinden önce verilerin basıklık ve çarpıklık değerleri ile normallik testi incelenmiș ve dağglımın normal olduğu belirlenmiștir. Verilerin normalliği KolmogorovSmirnov testi değişkenler arası farklar "t-test, tek yönlü varyans analizi (ANOVA), Tukey ve Games-Howell testleri kullanılmıstır.

Bulgular: Yapılan analizler sonucunda macera rekreasyonu katılımcılarının risk alma düzeyleri arasında cinsiyete bağlı etik, sağlık/güvenlik, rekreasyon alt boyutları ve DOSPERT toplam puanları arasında $(\mathrm{p}<0.01)$; etkinlik tercihlerine bağlı olarak etik, sağlık/güvenlik, sosyal ve rekreasyon alt boyutları arasında $(\mathrm{p}<0.01)$; etkinlik deneyimine bağlı olarak sağlı/güvenlik alt boyutunda $(\mathrm{p}<0.05)$; etkinliğin gerçekleştirilmesinde bağlı olunan kurum ve kuruluş dikkate alındığında ise sosyal alt boyunda $(\mathrm{p}<0.05)$ anlamlı farklılıkların olduğu tespit edilmiștir.

Sonuç: Macera rekreasyonu katılımcıların risk alma davranışları değerlendirildiğinde erkek

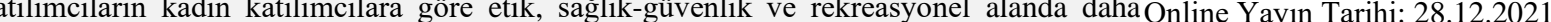
yüksek seviyede risk aldıkları belirlenmiştir. Bunun yanı sıra doğa yürüyüşü ve kampçılığı ile kayak yapan macera rekreasyonu katılımcılarının en düşük seviyede risk alma davranışı gösterdikleri; en deneyimli macera rekreasyonu katılımcılarının sağlık-güvenlik alanında en düşük seviyede risk alma davranışı gösterdikleri belirlenmiştir. Benzer şekilde külüp-dernek ve federasyona üye olarak macera rekreasyonu etkinliklerine katılanların sosyal anlamda daha düşük seviyede risk alma davranışı gösterdikleri söylenebilir. Son olarak etkinlik sıklığı veDOI:10.18826/useeabd.1002314 süresi değişkenine bağlı olarak katılımcıların risk alma davranış düzeylerinde bir değişim olmadığı belirlenmiștir.

\section{Examining the Variables That Make a Difference in the Risk-Taking Behaviors of Adventure Recreation Participants}

\begin{tabular}{lr}
\hline Abstract & Keywords \\
\hline Aim: The aim of the study is to examine the variables that make a difference in the risk-taking & Adventure Recreation, \\
behaviours of adventure recreation participants. & Risk Taking, \\
Methods: A total of $652(158$ women; $\bar{x}=34.59, S D=9.93$ years; 494 men; $\bar{x}=34.69, S D=9.41$ & DOSPERT,
\end{tabular}
years) adventure recreation participants from twelve different air, land and water-based activities participated in the study. Data were collected using a demographic questionnaire and the Domain-Specific Risk-Taking Scale (DOSPERT). Before the hypothesis tests, velues of kurtosis and skewness and test of normality of the data were examined and normal distribution was determined by the Kolmogorov-Smirnov, differences between variables were examined with "t-test, single-factor ANOVA" and "Tukey and Games-Howell" test analyses. Results: As a result of the analyses, significant differences were determined between the risk taking of adventure participants in total scores and the sub-dimensions of ethics, health/safety and recreation according to gender $(\mathrm{p}<0.01)$; in the sub-dimension of ethics, health/safety, social and recreation according to the activity preferences $(p<0.01)$; in the sub-dimension of health/safety according to the experience of the activity $(\mathrm{p}<0.05)$; in sub-dimension of social according to the institutional and organization that is affiliated in the realization of the activity $(\mathrm{p}<0.05)$.

Conclusion: When the risk-taking behaviors of the adventure recreation participants were evaluated, it was determined that male participants take a higher level of risk in ethics, health-

The role and contributions of each authors as in the section of IJSETS Writing Rules "Criteria for Authorship" is reported that: 1. Author: Contributions to the conception or design of the paper, data collection; 2. Author: Data collection, preparation of the paper according to rules of the journal, final approval of the version to be published paper.

Nevșehir Hacı Bektas Veli Üniversitesi Spor Bilimleri ve Teknolojisi Yüksekokulu, scem.dinc@ gmail.com ORCID ID: 0000-0001-6915-4540

${ }^{2}$ Manisa Celâl Bayar Üniversitesi, Sosyal Bilimler Enstitüsü ORCID ID: 0000-0002-1948-1620 
safety and recreation than female participants. In addition, participants of trekking and backpacking, and skiing takes the lowest level of risk; it was also determined that the most experienced adventure recreation participants showed the lowest level of risk-taking behavior in the field of health-safety. Similarly, it can be said that those who participate in adventure DOI:10.18826/useeabd.1002314 recreation activities as club-association and federation members show a low level of risktaking behavior in the field of social sense. Finally, it was determined that there was no change in the risk-taking behavior levels of the participants depending on the activity frequency and duration variable.

\section{GíRiş}

Doğa ve macera sporlarının artan kültürel görünürlüğü TV şovları ve yayınları, özel dergiler, filmler ve internet tabanlı medyanın da önemli etkisiyle tüm dünyada önemli sayıda katılımcıyı kendine çekmiştir (Wheaton, 2013). Uzun y1llardır katılımcılara yüksek derece heyecan yaşatan bu serbest zaman aktivitelerinin ortak özelliği yüksek sakatlık veya ölüm riskini içermesidir. Dolayısıyla bu tür etkinlikler yüksek risk içeren, ekstrem ya da macera etkinlikleri olarak adlandırılır (Guszkowska ve Boldak, 2010). Yüksek risk içeren bu sporlarda katılımcılar yaşamlarını tehlikeye atarak güçlü bir duygu peşinde koşarlar. Çevresel tehlikenin varlığı ile ortaya çıkan, değer verilen şeylerin kaybedilme potansiyeli olarak adlandırılan risk kavramı, macera rekreasyon programlarında etkinliğe yönlendiren temel nedenler arasında görülmekte ve katılım açısından en dikkat çekici durumsal değişken olarak karşımıza çıkmaktadır (Dinç, 2018).

Doğa ve macera sporlarının kayıtlanamayan gezici yapısı, katılım düzeylerini doğru bir şekilde ölçmeyi zorlaştırmasına rağmen (Gomes, Gustavo, Melo ve Pedragosa, 2017), özellikle batı toplumlarında geleneksel hale gelen sporlar arasinda (Wheaton 2013; Brymer ve Schweitzer 2017b) anılmaya başlandı. Başlangıçta, ağırlıklı olarak genç, eğitimli, yüksek nitelikli işlere ve dolayısıyla yüksek gelir ve sosyal statüye sahip erkekler tarafindan uygulanan doğa sporları (Melo ve Gomes, 2017), günümüzde demografik bir değişim göstererek (Brymer ve Schweitzer, 2017a), her yaş ve cinsiyetten, geniş ilgi ve deneyim yelpazesine sahip olan nüfusu kendine çeken karlı bir pazar halini aldı (Wheaton 2016; Brymer ve Schweitzer 2017b; Melo, Van Rheenen ve Gammon, 2020). Kat1lim tercihlerinin bu şekildeki dönüşümü, doğa ve macera etkinliklerinde risk ve heyecan arayan toplum profilinde de değişimin bir sonucu olarak algılandı. Geleneksel yaklaşımlar, riskli sporlara katılımı olumsuz, sosyal kabul görmeyen patolojik ve sapkın davranış eğilimleriyle bağdaştırmaktadır (Monasterio, 2012). Aslında macera içerisinde yer alan "risk algısı" bireysel özellik taşımaktadır. Dolayısıyla katılımcıların risk alma sebepleri ve risk alma dereceleri de bireysel olabileceği söylenebilir. Dickson ve Dolnicor (2004) riskin bireyden bireye değişkenlik göstereceğini hatta sadece fiziksel risklerin değil aynı zamanda sosyal ve psikolojik risklerin mümkün olduğuna ilişkin açılama getirmiş ve bir bireyin bazı şartlarda etkinliği risk olarak algılarken bazen ise grupla hareket etmeyi risk olarak algılayabileceğini ifade etmiştir. Araştırmacılar, insanın günlük yaşamının parçası olarak gördükleri risk almayı, maceranın deneyim ve tatmin sürecinde önemli bir role sahip olduğunu açıklayarak riskin yokluğunda macera rekreasyonu programlarına yönelik katılım isteğinde azalma olabileceğini belirtmişlerdir. MeiDan ve Carmont (2013), etkinliğe yönelik risk algısını, katılımcıya yönlendirilen izleyici görüşlerinin sonucu olduğunu belirterek katılımcıların ölüm ve sakatlanma dahil tüm risklerin farkında olduklarını ve üstesinden gelinemeyecek düzeyde risk almak yerine, riskleri en aza indirmek amaciyla yoğun eğitim veya pratik yaptıklarını belirtmişlerdir. Bunun yanında bir grup katılımcı, macerayı yüksek risk faktörü olarak görmek yerine riskleri deneyimin bir parçası olarak kabul eder ve durumu heyecan arayışı ve korkunun yarattığı bir tetikte olma hali olarak düşünürler. Bazıları ise kişisel gelişimin bir parçası olarak kabul ederler. Tüm bu açıklamaların yanısıra, macera rekreasyonu programlarında yer alan ve yüksek riskli doğa sporları etkinliklerine karşı insan organizmanın direnç göstermesine rağmen bireylerin neden hala risk alma eğiliminde bulunduklarına ilişkin net bir şey bulunamamıştır (Dinç, 2018). Bu durumun nedenlerinden birisi Brymer ve Schweitzer (2017a) tarafından ifade edildiği biçimde, risk ve heyecan arayışı temelli olgusal yaklaşımların kısıtlılığıdır. Çünkü etkinlikler yoluyla sağlanan deneyim ve pozitif sağlık faydaları katılımcılar tarafından geri plana atılmaktadır. Risk duyarlılığ teorisine göre ise risk alma eğilimi insan ve hayvanların içinde bulunduğu durum ve amaçları arasındaki farklılıktan kaynaklanmakta ve bu fark risk alma düzeyinin değişmesine neden olmaktadır (Mishra ve Lalumiére, 2010). Psikolojik araştırmalar konuya ilişkin farklı bir yaklaşım getirerek bütün risk alma davranışlarını benlik algısının yükselmesiyse bağdaştırmıştır. Heyecan arayışı üzerine kurgulanan çalışmalar ise kişilik özelliklerinin yansıması sonucu yüksek düzeyde risk almayı tercih eden ya da bu durumdan hoşnut olanların heyecan arayışına (sensation seeking) daha eğilimli insanlar olduğu hatta arzu ettikleri 
uyarılma düzeyine ulaşmak için risk alma davranışlarını da kullandıklarını ileri sürmektedir (Zuckerman, 1990; Dinç, 2018). Zuckerman'a (1990) göre heyecan arayışı, fizyolojik uyarılmayı artırmanın ve uyarılma ihtiyacını karşılamanın bir yolu olarak risk alma davranışları için bir motivasyon kaynağı olarak görünmektedir. Bu konuya açıklık getirmeye çalışan Ewert ve Sibthorp (2014) macera arayışını "belirsizlik içeren riskli ve heyecan verici tehlikeli girişim" anlamlarında kullanarak bir kültür veya tercih sonucu risk alma davranışını, dünya toplumlarının dokusuna aşılanmış bir fenomen olarak görmüştür. Dolayısıyla doğa, macera veya ekstrem sporlar, katılımcıların risk alma, mücadele, heyecan arayışı, başarıyı hissetme, uzmanlık ve kişisel becerilerin test edilmesine yönelik arzularını karşılamaktadır (Virden, 2006).

Özgürce seçilerek katılımcının ruh halini yansıtan, sonuçta içsel tatmin süreçleriyle şekillenen ve sonuçları belirsiz olan (Priest ve Gass, 2017) macera programları, etkinlik hedeflerini, kişilik özellikleri, bireysel beklenti ve tercihleri, yetenekleri, geçmiş deneyimleri sosyal ve fiziksel çevredeki gerçek ya da algılanan tehlikeleri bir araya getirmektedir (Ewert ve Sibthorp, 2014). Dolayısıyla başarılı macera deneyimleri, programa katılan bireylerin niteliklerinin gerçekçi biçimde değerlendirilerek uygun eğlence imkanlarının sunulmasını gerektirmektedir (Ewert ve Hollenhorst, 1995). Bu nitelikler arasında araştırmamız açısından en dikkat çekici olanı ise risk alma istekliliğidir. Konuya yönelik uluslararası deneysel ve betimsel araştırmalar Anglofon ağırlıklı bir literatürü ortaya çıkarmıştır. Yükssek riskli sporlarda deneyimlenen risk almanın yaşamı tehdit eden potansiyel sonuçları göz önüne alındığında, bazı insanları bu etkinlikleri benimsemeye yönlendirenin bir takım bireysel farklılıklar olduğu ortaya konulmuştur (Castanier, Scanff ve Woodman, 2010). Riskli sporlarda kişilik özelliklerinin risk alma davranışı üzerine etkisini inceledikleri çalışmalarında Castanier ve diğ., (2010) yüksek dışadönüklük ve/veya yüksek nevrotiklik (dürtüsel, hazc1, güvensiz) ile birlikte düşük vicdanlılık konfigürasyonuna sahip kişilik tiplerinin daha fazla risk alan kişiler olduğunu saptamışlardır. Özyeterlilik ve dürtüsellik gibi bireysel farklılıkların risk alma davranışındaki potansiyel rolünü incelemeyi amaçlayan bir başka çalışmada Llewellyn \& Sanchez, (2008), kaya tırmanıcılarının kendilerine meydan okumak için riskleri yönetme yeteneklerinden emin olduklarında hesaplanmış ek riskler alabildiğini, risk alan topluluklar içinde homojenlik olmamasına karşın insanların sadece heyecan arama ihtiyaçları nedeniyle tüm alanlarda risk aldıklarının varsayılamayacağını belirtmişlerdir. Brymer ve Oades, (2009), katılımcıların sahip olduğu önceki deneyimlerinin, daha zorlu etkinlikler yoluyla hayatını riske atmaya yönlendirebileceğini belirtmiştir. Risk alma davranışlarını etkileyebilecek bir diğer değişken de öz yeterlilik olarak açıklayan Llewellyn \& Sanchez, (2008), insanların risk almalarının nedenlerinden birinin, durumla başa çıkabileceklerine inanmaları ve öz-yeterlik duygularına sahip olmaları varsayımında bulunan Bandura (1997)'e atıfta bulunur. Bu durum heyecan arama, ustalık ve başarıy1 hissetme gibi ihtiyaçların yüksek riskli sporlara katılımın ana nedenleri olduğunu öne süren çalışmalarla tutarlı görülmektedir (Ewert ve Sibthorp, 2014). Doğal alan macera kazanımlarına yönelik güncel araştırmalar, geleneksel perspektife sahip risk alma ve korku duyma gibi sonuçlara orantısız biçimde odaklanan çalışmaların pozitif psikoloji yaklaşımıyla ortaya çıkan iyi olma hali değişkenini göz ardı ettiğini savunmaktadır (Houge Mackenzie ve Hodge, 2019; Seligman ve Csikszentmihalyi, 2014) Bunun sonucunda ise katılımcılara yönelik daha olumlu, gelişimsel motivasyon ve kazanımların gözden kaçırrılmakta olduğu belirtilmiştir. Benzer biçimde Houge Mackenzie ve Hodge, (2019) da macera deneyimleriyle ortaya çıkan olumlu öznel iyi oluş hali sonuçlarının belgelenmiş olmasına rağmen konunun çalışma ve analizlerde eksik bırakılmış olduğuna vurgu yapmıştır.

Şu ana kadar açıklandığı gibi çeşitli derleme ve meta analiz çalışmalarıyla ciddi düzeydeki uluslararası literature karşın (Melo ve diğ., 2020) ulusal literatürümüzde doğa, macera veya ekstrem etkinlik katılımcılarına ilişkin risk alma davranışı üzerine yapılmış deneysel ve betimsel çalışmalar oldukça kısıtlı düzeydedir. Türk literatüründeki bu çalışmalardan bazıları; üniversite öğrencilerinin etkinlik deneyimine bağlı risk algısı ve değerlendirmesi (Dinç, Koca, Demirhan ve Aşc1, 2004; Demirhan, Aş̧̧1, Kangalgil, Saraçbaşı, 2014), doğa sporları ve macera eğitim ve katılımının risk alma ve eleştirel düşünme üzerine etkisi (Dinç ve Saçlı Uzunöz ve Güneş, 2018), macera katılımda baskın beyin alanı, aleksitimi düzeyi ve risk alma davranış ilişkisi (Dinç ve Yavaş Tez, 2019-a), doğa sporlarına yönelik risk algılama düzeyidir (Demirhan, 2005). Mevcut çalışmalarda aleksitimi düzeyi yüksek ve dışa dönük kişilik özelliğine sahip doğa ve macera rekreasyonu katılımcılarının daha fazla risk alma eğiliminde olduğu (Dinç ve Yavaş Tez, 2019-a), erkek üniversite öğrencilerinin kadınlardan daha yüksek risk aldıkları (Dinç ve diğ., 2004; Demirhan ve diğ., 2014), doğa ve macera eğitimlerine katılımın özellikle rekreasyonel risk alma eğilimlerini arttırdığı (Dinç ve diğ., 2004), eleştirel düşünme eğilimlerinde artışa neden olduğu ancak bu farklılığın cinsiyetler arasında fark yaratmadığ (Dinç ve 
Saçlı Uzunöz ve Güneş, 2018), macera deneyim programına katılıma bağlı olarak bireylerin katıldıkları doğa sporların etkinlik risklerini daha düşük algılamaya başladığ ve bu durumun riske karşı olumlu eğilim veya duyarsızlaşmayı çağırıştırmakta olduğu sonuçları elde edilmiştir.

İnsanların iş, sosyal ve bireysel yaşam tercihlerinde kişisel karar verme süreçlerinde farklı yaklaşımlar gösterdiği aşikardır. Bu kişisel tercihler farklı araştırma sonuçlarıyla ortaya konulduğu gibi genellikle risk tutumundaki farklılıklar tarafindan tanımlanmakta veya açıklanmaktadır (Weber, Blais, Betz, 2002). Risk alma davranışının ölçümünde kullanılan DOSPERT-30 katılımcıların risk tutum derecesi ve algılananlarının değerlendirmelerini sağlar. Etik, finansal sağlık/güvenlik, sosyal ve rekreasyon kararlardaki risk almayı değerlendiren beş alt boyutlu bir ölçektir (Blais ve Weber, 2006). Sağlıkla ilgili risk alma eğilimi de dahil olmak üzere, bir dizi günlük durumdaki risk eğilimleri, risk algıları ve algılanan risk tutumu gibi çoklu risk yapılarının eşzamanlı ve doğrudan ölçtüğü için kullanımı literatürde siklıkla görülmektedir (Dinç ve Yavaş Tez, 2019-b) Blais ve Weber, 2006). Yaygın macera etkinlikleri katılımcılarının risk alma davranışlarını etkileyen faktörlerin belirlenmesine yönelik herhangi bir araştırmaya ulaşılamamıştır. Bu çerçevede çalışmanın amacı macera rekreasyonu katılımcılarının risk alma davranışlarında farklılık yaratan değişkenlerin incelenmesidir.

Demografik Değişkenler ve Hipotezler: Bu bölümde macera rekreasyonu katılımcılarının demografik özelliklerine bağlı olarak kurulan hipotezlere ilişkin istatistiksel test seçimleri ve bağımlı-bağımsız değişkenler sunulmuştur.

Tablo 1. Bağımlı-Bağımsız Değişkenler ve Araştırma Hipotezi

\begin{tabular}{ll}
\hline Bağımsız Değişkenler & \multicolumn{1}{c}{ Bağımlı Değişken } \\
\hline Cinsiyet (T-TESTİ) & \\
Yaş (ANOVA) & Etik (DOSPERT) \\
Eğitim Durumu (ANOVA) & Sağlı-Güvenlik (DOSPERT) \\
Etkinlik Tercihi (ANOVA) & Finans (DOSPERT) \\
Etkinlik Deneyimi (ANOVA) & Sosyal (DOSPERT) \\
Etkinliğin Gerçekleştirilme Sıklığı (ANOVA) & Rekreasyon (DOSPERT) \\
Etkinliğin Gerçekleştirilme Süresi (ANOVA) & DOSPERT ÖLÇEK TOPLAM \\
Etkinliğin Gerçekleştirilmesinde Bağlı Olunan Kurum/Kuruluş (ANOVA) & \\
\hline H0: Doğa ve macera rekreasyonu katılımcılarının risk alma davranış düzeyleri arasında demografik özelliklerine iliskkin fark yoktur. \\
H1: Doğa ve macera rekreasyonu katılımcılarının risk alma davranış düzeyleri arasında demografik özelliklerine ilişkin fark olacaktır. \\
P<.05, H1: Kabul, H0: Red & \\
P>.05, H1: Red, H0: Kabul &
\end{tabular}

\section{MATERYAL ve YÖNTEM}

\section{Katılimcilar}

Araştırmaya ilişkin veriler hava, su ve kara olmak üzere farklı kategoriler altında yer alan ve kolayda örnekleme metoduyla seçilen $652(\operatorname{kad} ı 158 \overline{\mathbf{X}}=34.59$ ss=9.93 yaş; erkek $494 \overline{\mathbf{X}}=34.69$, ss $=9.41$ yaş) macera rekreasyonu katılımcısından toplanmıştır.

\section{Veri Toplama Araçları}

Araştırmada macera rekreasyonu katılımcılarının demografik özellikleri kişisel bilgi formunda yer alan sorular ile belirlenirken; risk alma davranış düzeyleri Alana Özgü Risk Alma Ölçeği (DOSPERT) kullanılarak belirlenmiștir.

Alana Ö̈z̈̈̈ Risk Alma Ölçeği (DOSPERT): Weber, Blais, Betz (2002) tarafindan geliştirilen, Blais ve Weber (2006) tarafından kisa formu oluşturulan Dinç ve Yavaş Tez (2019-b) tarafindan kısa formunun geçerlik ve güvenirlik çalışmasının yapıldığ "DOSPERT-30 (A-Domain-Specific Risk-Taking Short Form)" kullanılmıştır. Ölçeğin Türk kültürü için geçerlik ve güvenirlik çalışmasının yapıldığı araştırmada ölçeğin 25 madde 5 alt boyut (etik, finansal, sağlık/güvenlik, rekreasyon, sosyal) olarak geçerliği ispatlanmıştır. Ölçek 7'li likert olup derecelendirmesi (1) Kesinlikle Hayır, (2) Muhtemelen Hayır, (3) Kısmen Hayır, (4) Kararsız, (5) Kısmen Evet, (6) Muhtemelen Evet, (7) Kesinlikle Evet şeklindedir. Ölçek, her bir alt boyut ya da tamamına ilişkin toplam puana göre çalışır ve ölçekten alınan yüksek puanlar yüksek risk alma eğilimini ifade eder. Ayrıca ölçek alt boyutları (tek bir alt boyut, iki alt boyut vb.) birbirinden bağımsız olarak çalışmalarda kullanıma uygunluğu ölçeğin Türk kültürü için yapılan geçerlik ve güvenirlik çalışmasında test edilmiştir.

\section{Verilerin Analizi}

Araştırma kapsamında yapılan istatistiksel analizler, SPSS 24 istatistik paket programı aracılığıyla gerçekleştirilmiştir. Verilerin değerlendirilmesinde istatistiki yöntem olarak; betimsel istatistikler (frekans, aritmetik ortalama, standart sapma); tek yönlü 
varyans analizi (ANOVA) ve Post-hoc testleri kullanılmıştır. Verilerin parametrik testlerin ön şartlarını sağlayıp sağlamadığına Skewness ve Kurtosis (+2 ile -2) değerleri incelenerek karar verilmiştir (Büyüköztürk, 2011). Ölçeklerin güvenirliklerini belirlemek için de Cronbach Alpha iç tutarlık katsayıları hesaplanmıştır.

\section{BULGULAR}

Bu bölümde, araştırmaya katılan macera rekreasyonu katılımcılarına ilişkin demografik özelliklere, veri toplama aracından aldıkları puanların dağılımına ve istatistik test sonuçlarına ilişkin bilgilere yer verilmiştir.

Tablo 2. Araştırmaya Katılan Macera Rekreasyonu Katılımcılarının Demografik Özellikleri

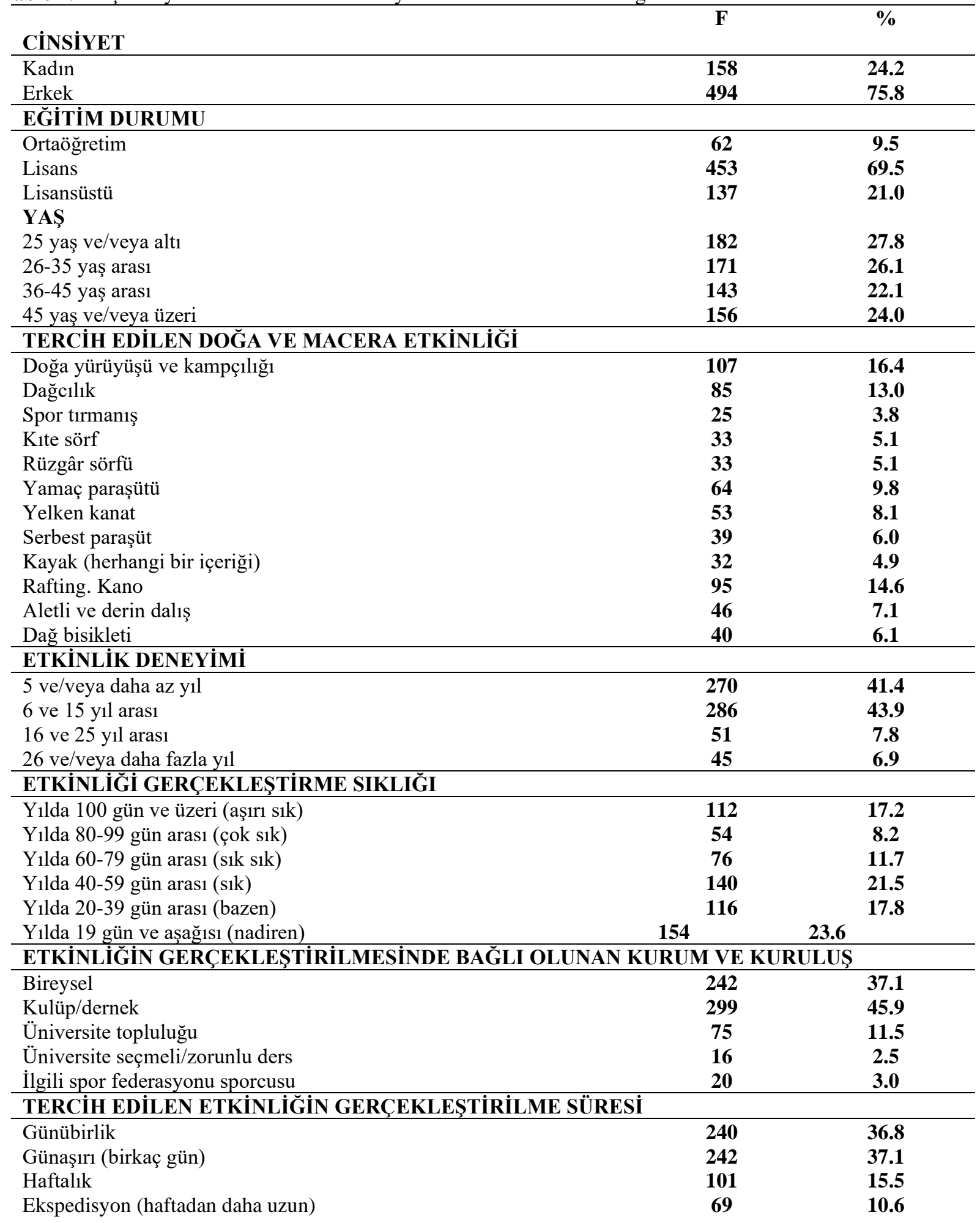


Tablo 3. Ölçek puanlarının dağılımı

\begin{tabular}{lccccccc}
\hline & Madde sayısı & $\overline{\mathbf{x}}$ & SS & Çarpıklık & Basıklık & Min. & Mak. \\
\hline Etik (DOSPERT) & 3 & 1,98 & 1,047 & 1,295 & 1,648 & 1.00 & 7.00 \\
Sağlık-Güvenlik (DOSPERT) & 5 & 3,16 & 1,297 & 0,710 & 0,094 & 1.00 & 7.00 \\
Finans (DOSPERT) & 5 & 2,31 & 1,130 & 1,221 & 1,793 & 1.00 & 7.00 \\
Sosyal (DOSPERT) & 6 & 4,68 & 1,078 & $-0,363$ & $-0,031$ & 1.00 & 7.00 \\
Rekreasyon (DOSPERT) & 6 & 4,78 & 1,471 & $-0,347$ & $-0,722$ & 1.00 & 7.00 \\
DOSPERT ÖLÇEK & 25 & 3,60 & 0,868 & 0,045 & $-0,138$ & 1.00 & 7.00 \\
\hline
\end{tabular}

Araştırma kapsamındaki macera rekreasyonu katılımcıların 'Alana Özgü Risk Alma Ölçeği (DOSPERT)'nin 'Etik' alt boyutundan aldıkları puanların aritmetik ortalaması 1.98 ve standart sapması 1.04'tür. 'Sağlık-Güvenlik' alt boyutundan aldıkları puanların aritmetik ortalaması ise 3.16 ve standart sapması 1.29 'dur. 'Finans' alt boyutundan aldıkları puanların aritmetik ortalaması ise 2.31 ve standart sapması 1.13 'dür. 'Sosyal' alt boyutundan aldıkları puanların aritmetik ortalaması ise 4.68 ve standart sapmas1 1.07 'dir. 'Rekreasyon' alt boyutundan aldıkları puanların aritmetik ortalamas1 ise 4.78 ve standart sapmas1 1.47 'dir. Diğer yandan macera rekreasyonu katılımcılarının Alana Özgü Risk Alma Ölçeği (DOSPERT)'den aldıkları puanların ortalaması ise 3.60 ve standart sapması 0.86 'dır. Ölçeklerden alınan puanların çarpıklık ve basıklık değerleri incelendiğinde verilerin normal dağılım gösterdiği söylenebilir. Araştırma kapsamında kullanılan ölçeğin (DOSPERT) sağlik/güvenlik, finans, etik alt boyutlarında ve ölçek toplamında Cronbach Alfa $(\alpha)$ değerleri "Etik $=0.78$; finans $=0.78$; sağlık/güvenlik $=0.76$; rekreasyon $=0.78$; sosyal $=0.75$; ölçek toplam $=0.86$ ) olarak belirlenmiştir.

\section{Araştırmadaki Farklılıklara İliş̧kin Hipotez Testi Sonuçları}

Bu bölümde 652 macera rekreasyonu katılımcısından elde edilen veriler doğrultusunda katılımciların demografik özelliklerine bağlı olarak kurulan hipotezlere ilişkin analiz sonuçları tablolar halinde verilmiştir.

Tablo 4. Macera Rekreasyonu Katılımcılarının Risk Alma Davranış Puanlarının Cinsiyet Değişkeni Bakımından Karşılaştırılması (T-Testi Sonuçları)

\begin{tabular}{|c|c|c|c|c|c|c|}
\hline & cinsiyet & $\mathbf{N}$ & Ortalama $\overline{\mathbf{x}}$ & $\operatorname{SS}(\sigma)$ & $\mathbf{T}$ & $\mathbf{p}$ \\
\hline \multirow{2}{*}{ Etik } & kadın & 158 & 4.84 & 2.20 & \multirow{2}{*}{-5.14} & \multirow{2}{*}{$0.00 * *$} \\
\hline & erkek & 494 & 6.28 & 3.31 & & \\
\hline \multirow{2}{*}{ Sağlık/Güvenlik } & kadin & 158 & 13.18 & 5.12 & \multirow{2}{*}{-5.98} & \multirow{2}{*}{$0.00 * *$} \\
\hline & erkek & 494 & 16.63 & 6.65 & & \\
\hline \multirow{2}{*}{ Finans } & kadın & 158 & 11.32 & 5.95 & \multirow{2}{*}{-0.59} & \multirow{2}{*}{0.55} \\
\hline & erkek & 494 & 11.63 & 5.55 & & \\
\hline \multirow{2}{*}{ Sosyal } & kadın & 158 & 27.37 & 6.22 & \multirow{2}{*}{-1.53} & \multirow{2}{*}{0.12} \\
\hline & erkek & 494 & 28.28 & 6.53 & & \\
\hline \multirow{2}{*}{ Rekreasyon } & kadın & 158 & 26.79 & 9.23 & \multirow{2}{*}{-3.11} & \multirow{2}{*}{$0.00 * *$} \\
\hline & erkek & 494 & 29.29 & 8.61 & & \\
\hline DOSPERT & kadın & 158 & 83.50 & 19.74 & \multirow{2}{*}{-4.40} & \multirow{2}{*}{$0.00 * *$} \\
\hline TOPLAM & erkek & 494 & 92.11 & 21.89 & & \\
\hline
\end{tabular}

Tablo 4'de risk alma ölçeğine ait "etik", "sağl1k/güvenlik", "rekreasyon" alt boyutları ve "DOSPERT toplam" puanlarının cinsiyete göre t-testi sonuçları incelendiğinde cinsiyet açısından kadın ve erkek arasında anlamlı farkl1lı olduğu görülmektedir $(\mathrm{t}=-5.14(\mathrm{E}) ;-5.98(\mathrm{~S} / \mathrm{G}) ;-3.11(\mathrm{R}) ;-4.40$ (DT) $\mathrm{p}<.01)$. Buna göre erkeklerin kadınlara göre ölçek toplam ve alt boyut puan ortalamalarının daha fazla olduğu ve bu durumun erkeklerin kadınlara göre daha fazla risk alma eğiliminde olduğu söylenebilir.

Tablo 5. Macera Rekreasyonu Katılımcılarının Risk Alma Davranış Puanlarının Yaş Değişkeni Bakımından Karşılaştırılması (ANOVA Sonuçları)

\begin{tabular}{|c|c|c|c|c|c|c|c|}
\hline & YAŞ ARALIĞI & $\mathbf{N}$ & $\begin{array}{c}\text { Ortalama } \\
\overline{\overline{\mathbf{x}}}\end{array}$ & $\mathbf{S S}(\sigma)$ & $\mathbf{F}$ & $\mathbf{P}$ & $\begin{array}{c}\text { Gruplar Arası } \\
\text { Farklar }\end{array}$ \\
\hline Etik & $\begin{array}{l}25 \mathrm{ve} / \mathrm{veya} \text { alt }{ }^{\mathrm{a}} \\
26 \text { ve } 35 \text { yaş aras }{ }^{\mathrm{b}}\end{array}$ & $\begin{array}{l}186 \\
166\end{array}$ & $\begin{array}{l}5.96 \\
5.87\end{array}$ & $\begin{array}{l}2.81 \\
3.21\end{array}$ & 0.04 & 0.98 & \\
\hline
\end{tabular}




\begin{tabular}{|c|c|c|c|c|c|c|c|}
\hline & 36 ve 45 yaş arası ${ }^{c}$ & 145 & 5.90 & 3.11 & & & \\
\hline & 45 ve/veya üzeri ${ }^{\mathrm{d}}$ & 155 & 5.99 & 3.47 & & & \\
\hline \multirow{4}{*}{ Sağlık/Güvenlik } & $25 \mathrm{ve} / \mathrm{veya}$ alt1 ${ }^{\mathrm{a}}$ & 186 & 16.65 & 6.52 & \multirow{4}{*}{2.47} & \multirow{4}{*}{0.06} & \\
\hline & 26 ve 35 yaş arası ${ }^{b}$ & 166 & 14.99 & 6.10 & & & \\
\hline & 36 ve 45 yaş arası ${ }^{c}$ & 145 & 15.23 & 6.40 & & & \\
\hline & 45 ve/veya üzeri ${ }^{\mathrm{d}}$ & 155 & 16.17 & 6.80 & & & \\
\hline \multirow{4}{*}{ Finans } & $25 \mathrm{ve} / \mathrm{veya}$ alt1 $^{\mathrm{a}}$ & 186 & 11.73 & 5.60 & \multirow{4}{*}{0.13} & \multirow{4}{*}{0.94} & \\
\hline & 26 ve 35 yaş arası ${ }^{b}$ & 166 & 11.48 & 5.43 & & & \\
\hline & 36 ve 45 yaş arası ${ }^{c}$ & 145 & 11.35 & 5.44 & & & \\
\hline & $45 \mathrm{ve} / \mathrm{veya}$ üzeri ${ }^{\mathrm{d}}$ & 155 & 11.61 & 6.14 & & & \\
\hline \multirow{4}{*}{ Sosyal } & $25 \mathrm{ve} / \mathrm{veya}$ alt1 ${ }^{\mathrm{a}}$ & 186 & 28.05 & 6.49 & \multirow{4}{*}{0.28} & \multirow{4}{*}{0.83} & \\
\hline & 26 ve 35 yaş arası ${ }^{b}$ & 166 & 27.70 & 5.91 & & & \\
\hline & 36 ve 45 yaş arası ${ }^{c}$ & 145 & 28.19 & 6.94 & & & \\
\hline & $45 \mathrm{ve} /$ veya üzeri ${ }^{\mathrm{d}}$ & 155 & 28.34 & 6.59 & & & \\
\hline \multirow{4}{*}{ Rekreasyon } & $25 \mathrm{ve} / \mathrm{veya}$ alt1 $^{\mathrm{a}}$ & 186 & 29.62 & 8.37 & \multirow{4}{*}{1.48} & \multirow{4}{*}{0.21} & \\
\hline & 26 ve 35 yaş arası ${ }^{b}$ & 166 & 27.72 & 9.26 & & & \\
\hline & 36 ve 45 yaş arası ${ }^{c}$ & 145 & 28.97 & 8.30 & & & \\
\hline & 45 ve/veya üzeri ${ }^{\mathrm{d}}$ & 155 & 28.32 & 9.29 & & & \\
\hline \multirow{4}{*}{$\begin{array}{l}\text { DOSPERT } \\
\text { Toplam }\end{array}$} & $25 \mathrm{ve} / \mathrm{veya}$ alt1 $^{\mathrm{a}}$ & 186 & 92.01 & 20.63 & \multirow{4}{*}{1.15} & \multirow{4}{*}{0.32} & \\
\hline & 26 ve 35 yaş arası ${ }^{b}$ & 166 & 87.77 & 20.68 & & & \\
\hline & 36 ve 45 yaş arası ${ }^{c}$ & 145 & 89.65 & 22.10 & & & \\
\hline & $45 \mathrm{ve} / \mathrm{veya}$ üzeri ${ }^{\mathrm{d}}$ & 155 & 90.43 & 23.50 & & & \\
\hline
\end{tabular}

Tablo-5'de görülebileceği gibi araştırmada yer alan macera rekreasyonu katılımcılarının yaş değişkenine ilişkin risk alma davranış düzeyleri arasında toplam ve alt boyutlar açısından istatistiksel olarak bir farklılaşma olup olmadığını anlamak için yapılan tek yönlü varyans analizi (ANOVA) sonucunda "DOSPERT Toplam" puanları ve "etik, sağlik/güvenlik, finans, sosyal, rekreasyon" alt boyutlarının yaş grupları arasında istatistiksel olarak anlamlı farklılıklar bulunmamıştır ( $\mathrm{F}=.04(\mathrm{E}) ; 2.47$ $(\mathrm{S} / \mathrm{G}) ; .13(\mathrm{~F}) ; .28(\mathrm{~S}) ; 1.48(\mathrm{R}) ; 1.15(\mathrm{DT}), \mathrm{p}>.05)$.

Tablo 6. Macera Rekreasyonu Katılımcılarının Risk Alma Davranış Puanlarının Eğitim Durumu Değişkeni Bakımından Karşılaştırılması (ANOVA ve Farklılıklara İlişkin Posthoc Analiz Sonuçları)

\begin{tabular}{|c|c|c|c|c|c|c|c|}
\hline & $\begin{array}{c}\text { EĞİTIM } \\
\text { DURUMU }\end{array}$ & $\mathbf{N}$ & $\begin{array}{c}\text { Ortalama } \\
\overline{\mathbf{x}} \\
\end{array}$ & $\operatorname{SS}(\sigma)$ & $\mathbf{F}$ & $\mathbf{P}$ & $\begin{array}{c}\text { Gruplar } \\
\text { Arası Farklar }\end{array}$ \\
\hline \multirow{3}{*}{ Etik } & Ortaöğretim $^{a}$ & 62 & 6.11 & 3.81 & \multirow{3}{*}{0.49} & \multirow{3}{*}{0.61} & \multirow{3}{*}{-------- } \\
\hline & Lisans ${ }^{b}$ & 453 & 5.98 & 3.07 & & & \\
\hline & Lisansüstü $^{\mathrm{c}}$ & 137 & 5.71 & 3.04 & & & \\
\hline \multirow{3}{*}{ Sağlık/Güvenlik } & Ortaöğretim $^{a}$ & 62 & 15.18 & 6.19 & \multirow{3}{*}{4.26} & \multirow{3}{*}{$0.01 *$} & \multirow{3}{*}{$b-c$} \\
\hline & Lisans ${ }^{b}$ & 453 & 16.27 & 6.75 & & & \\
\hline & Lisansüstü ${ }^{c}$ & 137 & 14.50 & 5.44 & & & \\
\hline \multirow{3}{*}{ Finans } & Ortaöğretim $^{\mathrm{a}}$ & 62 & 10.52 & 5.19 & \multirow{3}{*}{1.19} & \multirow{3}{*}{0.30} & \\
\hline & Lisans ${ }^{b}$ & 453 & 11.70 & 5.58 & & & ---------- \\
\hline & Lisansüstü $^{c}$ & 137 & 11.55 & 6.03 & & & \\
\hline \multirow{3}{*}{ Sosyal } & Ortaöğretim $^{\mathrm{a}}$ & 62 & 27.10 & 5.84 & \multirow{3}{*}{0.76} & \multirow{3}{*}{0.46} & \\
\hline & Lisans ${ }^{b}$ & 453 & 28.15 & 6.41 & & & --------- \\
\hline & Lisansüstü $^{c}$ & 137 & 28.20 & 6.91 & & & \\
\hline \multirow{3}{*}{ Rekreasyon } & Ortaöğretim $^{\mathrm{a}}$ & 62 & 27.60 & 8.88 & \multirow{3}{*}{1.91} & \multirow{3}{*}{0.14} & \\
\hline & Lisans ${ }^{b}$ & 453 & 29.13 & 8.70 & & & --------- \\
\hline & Lisansüstü ${ }^{c}$ & 137 & 27.69 & 9.14 & & & \\
\hline \multirow{3}{*}{$\begin{array}{l}\text { DOSPERT } \\
\text { Toplam }\end{array}$} & Ortaöğretim $^{\mathrm{a}}$ & 62 & 86.50 & 20.51 & \multirow{3}{*}{2.33} & \multirow{3}{*}{0.09} & \multirow{3}{*}{---------- } \\
\hline & Lisans ${ }^{b}$ & 453 & 91.23 & 21.79 & & & \\
\hline & Lisansüstü $^{c}$ & 137 & 87.66 & 21.69 & & & \\
\hline
\end{tabular}

Tablo 6'da görülebileceği gibi araştırmada macera rekreasyonu katılımcılarının eğitim durumu değişkenine göre risk alma düzeyleri arasında istatistiksel olarak bir farklılaşma olup olmadığını anlamak için yapılan tek yönlü varyans analizi (ANOVA) analizi sonucunda "DOSPERT" ölçeğine ait "sağlık/güvenlik" alt boyutunda anlamlı farklılıklar bulunmuştur $(\mathrm{F}=(\mathrm{S} / \mathrm{G}) ; 4.26, \mathrm{p}<0.05) . \mathrm{Bu}$ doğrultuda gruplar arası farklılıkların belirlenmesinde varyansların homojen olmadığı durumlarda seçilebilecek posthoc (Games-Howell/eşit olmayan varyans ve eşit olmayan örneklem) test sonuçları 
incelendiğinde DOSPERT ölçeğine ilişkin "sağlık/güvenlik" alt boyutunda lisans ( $\overline{\mathbf{x}}=16.27)$ ile lisansüstü ( $\overline{\mathbf{x}}=14.50)$ eğitim düzeyine sahip katılımcılar arasında istatistiksel olarak anlamlı farklılıklar olduğu görülmüsşür $(\mathrm{F}=4.26 \mathrm{p}<.05)$. Bu durum lisans eğitim düzeyine sahip katılımcıların lisansüstü eğitim düzeyine sahip katılımcılardan puan ortalamalarının fazla olması lisans düzeyindeki katılımcıların "sağlık/güvenlik" alt boyutuna ilişkin daha fazla risk alma eğiliminde olduğunu göstermektedir.

Tablo 7. Macera Rekreasyonu Katılımcılarının Risk Alma Davranış Puanlarının Etkinlik Tercihi Değişkeni Bakımından Karşılaştırılması (ANOVA ve Farklı1ıklara İlişkin Posthoc Analiz Sonuçları)

\begin{tabular}{|c|c|c|c|c|c|c|c|}
\hline & ETKİNLİKLER & $\mathbf{N}$ & $\begin{array}{c}\text { Ortalama } \\
\overline{\mathbf{x}} \\
\end{array}$ & $\mathbf{S S}(\sigma)$ & $\mathbf{F}$ & $\mathbf{P}$ & $\begin{array}{c}\text { Gruplar Arası } \\
\text { Farklar }\end{array}$ \\
\hline \multirow[t]{12}{*}{ Etik } & Doğa yürüyüşü ve kampçılığ ${ }^{a}$ & 107 & 4.95 & 2.575 & \multirow{12}{*}{2.19} & \multirow{12}{*}{$0.01 *$} & \multirow{12}{*}{$\begin{array}{c}\text { a-b / a-c } \\
\text { a-e / a-f } \\
\text { a-g / a-h } \\
\text { a-j / a-k } \\
\text { a-l } \\
\text { i-b / i-c } \\
\text { i-e / i-g } \\
\text { i-h / i-k } \\
\text { i-l }\end{array}$} \\
\hline & Dağcıllık ${ }^{b}$ & 85 & 6.31 & 3.226 & & & \\
\hline & Spor tırmanış ${ }^{c}$ & 25 & 6.52 & 2.679 & & & \\
\hline & Kite sörf ${ }^{\mathrm{d}}$ & 33 & 5.33 & 2.618 & & & \\
\hline & Rüzgâr sörfü e & 33 & 6.73 & 3.439 & & & \\
\hline & Yamaç paraşütü $^{\mathrm{f}}$ & 64 & 5.94 & 3.299 & & & \\
\hline & Yelken kanat $\mathrm{g}$ & 53 & 6.38 & 3.077 & & & \\
\hline & Serbest paraşüt ${ }^{h}$ & 39 & 6.44 & 3.315 & & & \\
\hline & Kayak (herhangi bir içeriği) ${ }^{i}$ & 32 & 5.00 & 3.253 & & & \\
\hline & Rafting. Kano ${ }^{j}$ & 95 & 5.82 & 3.558 & & & \\
\hline & Aletli veya derin dalış ${ }^{\mathrm{k}}$ & 46 & 6.39 & 2.695 & & & \\
\hline & Dağ bisikleti ${ }^{1}$ & 40 & 6.63 & 3.224 & & & \\
\hline Sağlik / & Doğa yürüyüşü ve kampçılığ ${ }^{a}$ & 107 & 13.73 & 5.383 & \multirow{12}{*}{2.59} & \multirow{12}{*}{$0.00 * *$} & \\
\hline \multirow[t]{11}{*}{ Güvenlik } & Dağcc1lık ${ }^{b}$ & 85 & 15.44 & 6.424 & & & \\
\hline & Spor tırmanış ${ }^{c}$ & 25 & 15.48 & 4.744 & & & \\
\hline & Kite sörf ${ }^{d}$ & 33 & 15.91 & 8.044 & & & \\
\hline & Rüzgâr sörfü e & 33 & 17.58 & 7.770 & & & \\
\hline & Yamaç paraşütü $^{\mathrm{f}}$ & 64 & 16.86 & 6.978 & & & $a-g$ \\
\hline & Yelken kanat $^{g}$ & 53 & 18.08 & 6.950 & & & $a-j$ \\
\hline & Serbest paraşüt ${ }^{h}$ & 39 & 16.41 & 7.206 & & & \\
\hline & Kayak (herhangi bir içeriği) ${ }^{\text {i }}$ & 32 & 16.06 & 6.350 & & & \\
\hline & Rafting. Kano ${ }^{j}$ & 95 & 16.71 & 6.606 & & & \\
\hline & Aletli veya derin dalış ${ }^{\mathrm{k}}$ & 46 & 14.76 & 5.494 & & & \\
\hline & Dağ bisikleti ${ }^{1}$ & 40 & 14.23 & 4.688 & & & \\
\hline \multirow[t]{12}{*}{ Finans } & Doğa yürüyüşü ve kampç1lığ ${ }^{a}$ & 107 & 11.21 & 5.517 & \multirow{12}{*}{1.78} & \multirow{12}{*}{0.05} & \\
\hline & Dağccllık ${ }^{b}$ & 85 & 11.39 & 5.352 & & & \\
\hline & Spor tırmanış ${ }^{c}$ & 25 & 14.52 & 7.838 & & & \\
\hline & Kite sörf ${ }^{\mathrm{d}}$ & 33 & 11.15 & 6.129 & & & \\
\hline & Rüzgâr sörfü ${ }^{\mathrm{e}}$ & 33 & 13.58 & 6.031 & & & \\
\hline & Yamaç paraşütü ${ }^{\mathrm{f}}$ & 64 & 11.22 & 4.644 & & & \\
\hline & Yelken kanat $\mathrm{g}$ & 53 & 11.74 & 5.223 & & & 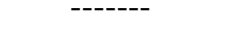 \\
\hline & Serbest paraşüt ${ }^{h}$ & 39 & 12.36 & 5.081 & & & \\
\hline & Kayak (herhangi bir içeriği) ${ }^{i}$ & 32 & 9.75 & 4.765 & & & \\
\hline & Rafting. Kano ${ }^{j}$ & 95 & 10.66 & 5.467 & & & \\
\hline & Aletli veya derin dalış ${ }^{\mathrm{k}}$ & 46 & 11.83 & 5.689 & & & \\
\hline & Dağ bisikleti $^{1}$ & 40 & 12.38 & 7.103 & & & \\
\hline \multirow[t]{12}{*}{ Sosyal } & Doğa yürüyüşü ve kampçılığ ${ }^{a}$ & 107 & 25.95 & 6.449 & \multirow{12}{*}{3.16} & \multirow{12}{*}{$0.00 * *$} & \\
\hline & Dağcilık ${ }^{b}$ & 85 & 29.27 & 6.050 & & & \\
\hline & Spor tırmanış ${ }^{c}$ & 25 & 28.48 & 6.131 & & & \\
\hline & Kite sörf ${ }^{d}$ & 33 & 25.15 & 7.203 & & & \\
\hline & Rüzgâr sörfü ${ }^{e}$ & 33 & 27.91 & 5.886 & & & $a-b$ \\
\hline & Yamaç paraşütü $^{\mathrm{f}}$ & 64 & 28.70 & 6.296 & & & $a-h$ \\
\hline & Yelken kanat ${ }^{g}$ & 53 & 29.32 & 5.584 & & & d-h \\
\hline & Serbest paraşüt ${ }^{h}$ & 39 & 30.97 & 6.515 & & & \\
\hline & Kayak (herhangi bir içeriği) ${ }^{i}$ & 32 & 26.78 & 7.356 & & & \\
\hline & Rafting. Kano ${ }^{j}$ & 95 & 28.54 & 6.897 & & & \\
\hline & Aletli veya derin dalış ${ }^{\mathrm{k}}$ & 46 & 27.70 & 5.834 & & & \\
\hline & Dağ bisikleti $^{1}$ & 40 & 28.18 & 5.733 & & & \\
\hline \multirow[t]{2}{*}{ Rekreasyon } & Doğa yürüyüşü ve kampçılığ ${ }^{a}$ & 107 & 24.76 & 9.128 & \multirow{2}{*}{5.14} & \multirow{2}{*}{$0.00 * *$} & $a-b$ \\
\hline & Dağcrlık ${ }^{b}$ & 85 & 29.79 & 8.540 & & & a-e \\
\hline
\end{tabular}




\begin{tabular}{|c|c|c|c|c|c|c|c|}
\hline & Spor tırmanış ${ }^{c}$ & 25 & 30.00 & \multicolumn{3}{|l|}{9.188} & $a-f$ \\
\hline & Kite sörf ${ }^{d}$ & 33 & 26.73 & \multicolumn{3}{|l|}{9.602} & $\mathrm{a}-\mathrm{g}$ \\
\hline & Rüzgâr sörfü e & 33 & 30.42 & \multicolumn{3}{|l|}{8.544} & $\mathrm{a}-\mathrm{h}$ \\
\hline & Yamaç paraşütü ${ }^{\mathrm{f}}$ & 64 & 29.94 & \multicolumn{3}{|l|}{7.226} & $a-j$ \\
\hline & Yelken kanat $^{\mathrm{g}}$ & 53 & 30.40 & \multicolumn{3}{|l|}{6.854} & $a-1$ \\
\hline & Serbest paraşüt ${ }^{h}$ & 39 & 32.74 & \multicolumn{3}{|l|}{8.006} & $\mathrm{~b}-\mathrm{k}$ \\
\hline & Kayak (herhangi bir içeriği) ${ }^{\mathrm{i}}$ & 32 & 27.22 & \multicolumn{3}{|l|}{8.728} & f-k \\
\hline & Rafting. Kano ${ }^{j}$ & 95 & 30.23 & \multicolumn{3}{|l|}{8.813} & $\mathrm{~g}-\mathrm{k}$ \\
\hline & Aletli veya derin dalış ${ }^{k}$ & 46 & 24.50 & \multicolumn{3}{|l|}{9.050} & $\mathrm{~h}-\mathrm{k}$ \\
\hline & Dağ bisikleti $^{1}$ & 40 & 30.25 & \multicolumn{3}{|l|}{8.527} & $\mathrm{j}-\mathrm{k}$ \\
\hline DOSPERT & Doğa yürüyüşü ve kampçılı̆ğ ${ }^{a}$ & 107 & 80.61 & 20.440 & \multirow{12}{*}{4.20} & \multirow{12}{*}{$0.00 * *$} & \\
\hline \multirow{11}{*}{ Toplam } & Dağcılık & 85 & 92.19 & 21.692 & & & \\
\hline & Spor tırmanış ${ }^{\mathrm{c}}$ & 25 & 95.00 & 21.953 & & & \\
\hline & Kite sörf ${ }^{d}$ & 33 & 84.27 & 26.286 & & & $a-b$ \\
\hline & Rüzgâr sörfü e & 33 & 96.21 & 23.437 & & & $\mathrm{a}-\mathrm{e}$ \\
\hline & Yamaç paraşütü ${ }^{\mathrm{f}}$ & 64 & 92.66 & 19.455 & & & $a-f$ \\
\hline & Yelken kanat $^{\mathrm{g}}$ & 53 & 95.91 & 18.311 & & & $\mathrm{a}-\mathrm{g}$ \\
\hline & Serbest paraşüt ${ }^{h}$ & 39 & 98.92 & 20.781 & & & $\mathrm{a}-\mathrm{h}$ \\
\hline & Kayak (herhangi bir içeriği) ${ }^{i}$ & 32 & 84,81 & 19,350 & & & $a-j$ \\
\hline & Rafting. Kano ${ }^{j}$ & 95 & 91,96 & 22,109 & & & \\
\hline & Aletli veya derin dalış ${ }^{\mathrm{k}}$ & 46 & 85,17 & 20,478 & & & \\
\hline & Dağ bisikleti ${ }^{1}$ & 40 & 91,65 & 20,663 & & & \\
\hline
\end{tabular}

Tablo 7'de görülebileceği gibi araştırmada yer alan macera rekreasyonu katılımcılarının etkinlik tercihi değişkenine göre DOSPERT alt boyutları arasında istatistiksel olarak bir farklılaşma olup olmadığını anlamak için yapılan tek yönlü varyans analizi (ANOVA) sonucunda DOSPERT toplam ve alt boyutları ile etkinlik tercihleri arasında anlamlı farklılıklar bulunmuştur $(\mathrm{F}=(\mathrm{E}) ; 2.19(\mathrm{~S} / \mathrm{G}) ; 2.59$; (S); 3.16 (R); 5.14 (DT); 4.20 p>.05). Etkinlik tercihlerinin hangi gruplar arasında farklılaştığını bulmak amacıyla posthoc analizlerinden varyansların homojen olduğu durumlarda seçilebilecek "Scheffe testi /karşılaştırılacak grup sayısının çok olduğu durumda, gruplardaki gözlem sayısını dikkate almaz" ve varyansların homojen olmadığı durumlarda seçilebilecek "Games-Howell testi /eşit olmayan varyans ve eşit olmayan örneklem" sonuçlarına bakılmıştır. Buna göre DOSPERT alt boyutları arasında yer alan "etik, sosyal, Rekreasyon, sağlık/güvenlik" alt boyutları açısından farklılıklar incelendiğinde etik boyutu için doğa yürüyüşü ve kampçıllı̆̆ $(\overline{\mathbf{x}}=4.95)$ ile uğraşan macera rekreasyonu katılımcılarının kite sörf $(\overline{\mathbf{x}}=5.33)$ ve kayak (herhangi bir içeriği) ile uğraşan katılımcılar hariç bütün macera rekreasyonu etkinliklerine katılan katılımcılar arasında anlamlı farklılıklar bulunmuştur. Benzer şekilde dağcılık $(\overline{\mathbf{x}}=6.31)$ ile uğraşanların kayak (herhangi bir içeriği) $(\overline{\mathbf{x}}=5.00)$ ile uğraşanlar arasında anlamlı farklılıklar bulunmuştur. Kayak (herhangi bir içeriği) $(\overline{\mathbf{x}}=5.00)$ ile uğraşanlar ile dağ bisikleti $(\overline{\mathbf{x}}=6.63)$ ile uğraşanlar arasında anlamlı farklılıklar bulunmuştur. Kayak (herhangi bir içeriği) $(\overline{\mathbf{x}}=5.00)$ ile uğraşanların hem yelkenkanat $(\overline{\mathbf{x}}=6.38)$ hem de rüzgar sörfü $(\overline{\mathbf{x}}=6.73)$ ile uğraşanlar arasında anlamlı farklılıklar bulunmuştur. Sosyal alt boyut incelendiğinde serbest paraşüt $(\overline{\mathbf{x}}=30.97)$ ile kite sörf $(\overline{\mathbf{x}}=25.15)$ arasında farkl11ıklar görülürken benzer şekilde doğa yürüyüşü ve kampçılığıyla uğraşanların $(\overline{\mathbf{x}}=25.95)$ dağcılık (herhangi bir içeriği) $(\overline{\mathbf{x}}=29.27)$ ve serbest paraşüt $(\overline{\mathbf{x}}=30.97)$ ile uğraşan katılımcılar arasında sosyal alt boyut açısından anlamlı farklılıklar bulunmuştur. Rekreasyon alt boyutu değerlendirildiğinde doğa yürüyüş̧ü ve kampçılığıyla uğraşanların ( $\overline{\mathbf{x}}=24.76$ ) dağcılık (herhangi bir içeriği) $(\overline{\mathbf{x}}=29.79)$, rüzgar sörfü ( $\overline{\mathbf{x}}=30.42)$, yamaç paraşütü $(\overline{\mathbf{x}}=29.94)$, yelken kanat $(\overline{\mathbf{x}}=30.40)$, serbest paraşüt ( $\overline{\mathbf{x}}=32.74)$, raftingkano $(\overline{\mathbf{x}}=30.23)$ ile uğraşan katılımcılar arasında anlamlı farklılıklar bulunurken; aletli ve/veya derin dalış $(\overline{\mathbf{x}}=24.50)$ ile uğraşan katılımcıların dağc1lık $(\overline{\mathbf{x}}=29.79)$, yamaç paraşütü $(\overline{\mathbf{x}}=29.94)$, yelken kanat $(\overline{\mathbf{x}}=30.40)$, serbest paraşüt $(\overline{\mathbf{x}}=32.74)$, kayak (herhangi bir içeriği) $(\overline{\mathbf{x}}=27.22)$ ile uğraşan katılımcılarla aralarında anlamlı farklılıklar bulunmuştur. Sağlık/güvenlik alt boyutu değerlendirildiğinde doğa yürüyüşü ve kampç1lığ $(\overline{\mathbf{x}}=13.73)$ ile uğraşanların hem yelken kanat $(\overline{\mathbf{x}}=18.08)$ hem de rafting-kano $(\overline{\mathbf{x}}=16.71)$ ile uğraşan katılımcılar arasında anlamlı farklılıklar olduğu görülmektedir. Ölçeğe ilişkin toplam puanlar açısından gruplar arasındaki farklılıklar değerlendirildiğinde doğa yürüyüşü ve kampçılığıyla $(\overline{\mathbf{x}}=80.61)$ uğraşan katılımcılar ile dağcılık $(\overline{\mathbf{x}}=92.19)$, rüzgar sörfü $(\overline{\mathbf{x}}=96.21)$, yamaç paraşütü ( $\overline{\mathbf{x}}=92.66)$, yelken kanat ( $\overline{\mathbf{x}}=95.91)$, serbest paraşüt $(\overline{\mathbf{x}}=98.92)$, rafting-kano $(\overline{\mathbf{x}}=91.96)$ ile uğraşan katılımcılar arasında istatistiksel olarak anlamlı farklılıklar bulunmuştur. 
Tablo 8. Macera Rekreasyonu Katılımcılarının Risk Alma Davranış Puanlarının Etkinlik Deneyim Durumu Değişkeni Bakımından Karşılaştırılması (ANOVA ve Farklılıklara İlişkin Posthoc Analiz Sonuçları)

\begin{tabular}{|c|c|c|c|c|c|c|c|}
\hline & DENEYİM DURUMU & $\mathbf{N}$ & $\begin{array}{c}\text { Ortalama } \\
\overline{\mathbf{x}} \\
\end{array}$ & $\operatorname{SS}(\sigma)$ & $\mathbf{F}$ & $\mathbf{P}$ & $\begin{array}{c}\text { Gruplar Arası } \\
\text { Farklar }\end{array}$ \\
\hline \multirow[t]{4}{*}{ Etik } & 5 ve/veya daha az yıl ${ }^{\text {a }}$ & 270 & 5.83 & 3.02 & & & \\
\hline & 6 ve 15 y1l arass ${ }^{b}$ & 286 & 5.95 & 3.22 & & & \\
\hline & 16 ve 25 y1l arasi ${ }^{c}$ & 51 & 6.55 & 3.26 & .80 & .49 & ---------- \\
\hline & $26 \mathrm{ve} / \mathrm{veya}$ daha fazla yıl ${ }^{\mathrm{d}}$ & 45 & 5.76 & 3.17 & & & \\
\hline \multirow[t]{4}{*}{ Sağlik/Güvenlik } & 5 ve/veya daha az yıl ${ }^{\text {a }}$ & 270 & 16.20 & 6.55 & & & \\
\hline & 6 ve 15 y1l arasi ${ }^{b}$ & 286 & 15.97 & 6.58 & & & $a-d$ \\
\hline & 16 ve 25 yıl aras $1^{c}$ & 51 & 14.49 & 6.49 & 2.65 & $.04 *$ & $b-d$ \\
\hline & $26 \mathrm{ve} / \mathrm{veya}$ daha fazla yıl ${ }^{\mathrm{d}}$ & 45 & 13.73 & 4.84 & & & \\
\hline \multirow[t]{4}{*}{ Finans } & 5 ve/veya daha az yıl ${ }^{\text {a }}$ & 270 & 11.33 & 5.19 & & & \\
\hline & 6 ve 15 yil aras ${ }^{b}$ & 286 & 11.78 & 5.95 & & & \\
\hline & 16 ve 25 y1l arasi ${ }^{c}$ & 51 & 12.00 & 6.38 & .59 & .62 & --------- \\
\hline & $26 \mathrm{ve} / \mathrm{veya}$ daha fazla yıl ${ }^{\mathrm{d}}$ & 45 & 10.91 & 5.43 & & & \\
\hline \multirow[t]{4}{*}{ Sosyal } & 5 ve/veya daha az yıl ${ }^{\text {a }}$ & 270 & 27.63 & 6.44 & & & \\
\hline & 6 ve 15 y1l arasi ${ }^{b}$ & 286 & 28.47 & 6.27 & & & \\
\hline & 16 ve 25 yıl arasi ${ }^{c}$ & 51 & 27.80 & 7.92 & .83 & .47 & --------- \\
\hline & $26 \mathrm{ve} / \mathrm{veya}$ daha fazla yıl ${ }^{\mathrm{d}}$ & 45 & 28.38 & 6.02 & & & \\
\hline \multirow[t]{4}{*}{ Rekreasyon } & $5 \mathrm{ve} / \mathrm{veya}$ daha az yıl ${ }^{\text {a }}$ & 270 & 28.74 & 8.51 & & & \\
\hline & 6 ve 15 y1l arass ${ }^{b}$ & 286 & 28.91 & 8.95 & & & \\
\hline & 16 ve 25 yıl aras $1^{c}$ & 51 & 26.61 & 9.70 & 1.06 & .36 & ---------- \\
\hline & $26 \mathrm{ve} / \mathrm{veya}$ daha fazla yıl ${ }^{\mathrm{d}}$ & 45 & 29.22 & 8.84 & & & \\
\hline DOSPERT & 5 ve/veya daha az yıl a & 270 & 89.74 & 21.01 & & & \\
\hline \multirow[t]{3}{*}{ Toplam } & 6 ve 15 y1l arasi ${ }^{b}$ & 286 & 91.08 & 21.96 & .60 & .60 & ---------- \\
\hline & 16 ve 25 y1l aras ${ }^{c}$ & 51 & 87.45 & 25.45 & & & \\
\hline & 26 ve/veya daha fazla yıl ${ }^{\mathrm{d}}$ & 45 & 88.00 & 19.61 & & & \\
\hline
\end{tabular}

Tablo 8'de görülebileceği gibi araştırmada yer alan macera rekreasyonu katılımcılarının etkinlik deneyim durumu değişkenine göre risk alma düzeyleri arasında istatistiksel olarak bir farklılaşma olup olmadığını anlamak için yapılan tek yönlü varyans analizi (ANOVA) sonucunda DOSPERT ölçeğine ait "sağlık/güvenlik" alt boyutu ile etkinlik deneyim durumları arasında anlamlı farklılıklar bulunmuştur $(\mathrm{F}=(\mathrm{S} / \mathrm{G}) ; 2.65, \mathrm{p}<.05)$. Etkinlik deneyim durumlarına yönelik farklılıkların hangi gruplar arasında olduğunu belirlemek amacıyla posthoc analizlerinden varyansların homojen olmadığ 1 durumlarda seçilebilecek "Games-Howell/eşit olmayan varyans ve eşit olmayan örneklem" test sonuçlarına bakılmıştır. Buna göre DOSPERT alt boyutları arasında yer alan "sağlık/güvenlik" açısından 5 ve/veya daha az yıl ( $(\overline{\mathbf{x}}=16.20)$ deneyime sahip olan doğa ve macera rekreasyonu katılımcıları ile 26 ve daha fazla y1l ( $\overline{\mathbf{x}}=13.73)$ deneyime sahip katılımcılar arasında anlamlı farklılıklar bulunmuştur. Benzer şekilde 6 ve 15 yıl arası ( $\overline{\mathbf{x}}=15.97)$ deneyime sahip katılımcilar ile 26 ve daha fazla y1l $(\overline{\mathbf{x}}=13.73)$ deneyime sahip katılımcılar arasında anlamlı farklılıklar bulunmuştur.

Tablo 9. Katılımcıların Risk Alma Davranış Puanlarının Etkinliğin Gerçekleştirilme Sıklığı Değişkeni Bakımından Karşılaştırılması (ANOVA Sonuçları)

\begin{tabular}{|c|c|c|c|c|c|c|c|}
\hline & ETKİNLİK SIKLIĞI & $\mathbf{N}$ & $\overline{\mathbf{x}}$ & $\operatorname{SS}(\sigma)$ & $\mathbf{F}$ & $\mathbf{P}$ & $\begin{array}{c}\text { Gruplar Arası } \\
\text { Farklar }\end{array}$ \\
\hline \multirow{6}{*}{ Etik } & Yılda 100 gün ve üzeri (aşırı sık) ${ }^{a}$ & 112 & 6.24 & 3.514 & \multirow{6}{*}{1.44} & \multirow{6}{*}{0.20} & \multirow{6}{*}{---------- } \\
\hline & Y1lda 80-99 gün arası (çok sık) b & 54 & 6.31 & 3.330 & & & \\
\hline & Yılda 60-79 gün arası (sık s1k) ${ }^{\mathrm{c}}$ & 76 & 5.57 & 2.806 & & & \\
\hline & Y1lda 40-59 gün arası (sık) ${ }^{d}$ & 140 & 5.89 & 3.098 & & & \\
\hline & Yılda 20-39 gün arası (bazen) ${ }^{\mathrm{e}}$ & 116 & 6.30 & 3.429 & & & \\
\hline & Y1lda 19 gün ve aşağısı(nadiren) ${ }^{\mathrm{f}}$ & 154 & 5.52 & 2.706 & & & \\
\hline \multirow{6}{*}{$\begin{array}{l}\text { Sağlik } \\
\text { /Güvenlik }\end{array}$} & Yılda 100 gün ve üzeri (aşırı sık) ${ }^{a}$ & 112 & 16.48 & 6.644 & \multirow{6}{*}{1.00} & \multirow{6}{*}{0.41} & \multirow{6}{*}{---------- } \\
\hline & Yılda 80-99 gün arası (çok sık) b & 54 & 16.74 & 7.072 & & & \\
\hline & Yılda 60-79 gün arası (sık s1k) ${ }^{c}$ & 76 & 15.32 & 7.092 & & & \\
\hline & Yılda 40-59 gün arası (sık) ${ }^{d}$ & 140 & 15.47 & 6.292 & & & \\
\hline & Y1lda 20-39 gün arası (bazen) ${ }^{\mathrm{e}}$ & 116 & 15.03 & 6.181 & & & \\
\hline & Y1lda 19 gün ve aşağısı(nadiren) ${ }^{\mathrm{f}}$ & 154 & 16.07 & 6.229 & & & \\
\hline \multirow{2}{*}{ Finans } & Y1lda 100 gün ve üzeri (aşırı sık) ${ }^{a}$ & 112 & 11.62 & 5.881 & \multirow{2}{*}{1.48} & \multirow{2}{*}{0.19} & \multirow[t]{2}{*}{----------- } \\
\hline & Y1lda 80-99 gün arası (çok sık) b & 54 & 10.89 & 5.755 & & & \\
\hline
\end{tabular}




\begin{tabular}{|c|c|c|c|c|c|c|c|}
\hline & Y1lda 60-79 gün arası (sık sık) ${ }^{c}$ & 76 & 10.30 & 4.880 & & & \\
\hline & Y1lda 40-59 gün arası (s1k) ${ }^{d}$ & 140 & 11.79 & 5.369 & & & \\
\hline & Y1lda 20-39 gün arası (bazen) ${ }^{\mathrm{e}}$ & 116 & 12.41 & 5.794 & & & \\
\hline & Yilda 19 gün ve aşağısı(nadiren) ${ }^{\mathrm{f}}$ & 154 & 11.50 & 5.888 & & & \\
\hline \multirow{6}{*}{ Sosyal } & Yılda 100 gün ve üzeri (aşırı sık) ${ }^{a}$ & 112 & 28.49 & 6.990 & \multirow{6}{*}{0.53} & \multirow{6}{*}{0.74} & \\
\hline & Yılda 80-99 gün arası (çok sık) ${ }^{b}$ & 54 & 28.31 & 7.148 & & & \\
\hline & Yılda 60-79 gün arası (sık sık) ${ }^{\mathrm{c}}$ & 76 & 27.24 & 6.186 & & & \\
\hline & Y1lda 40-59 gün arası (s1k) ${ }^{d}$ & 140 & 28.44 & 6.372 & & & \\
\hline & Yılda 20-39 gün arası (bazen) e & 116 & 28.06 & 6.691 & & & \\
\hline & Y1lda 19 gün ve aşağısı(nadiren) ${ }^{\mathrm{f}}$ & 154 & 27.73 & 5.913 & & & \\
\hline \multirow{6}{*}{ Rekreasyon } & Yılda 100 gün ve üzeri (aşırı sık) ${ }^{a}$ & 112 & 29,79 & 9,057 & \multirow{6}{*}{1,94} & \multirow{6}{*}{0.08} & \\
\hline & Yılda 80-99 gün arası (çok sık) ${ }^{b}$ & 54 & 30,89 & 8,229 & & & \\
\hline & Yılda 60-79 gün arası (sık sık) ${ }^{\mathrm{c}}$ & 76 & 27,71 & 9,632 & & & \\
\hline & Y1lda 40-59 gün arası (sık) ${ }^{d}$ & 140 & 29,25 & 8,952 & & & \\
\hline & Y1lda 20-39 gün arası (bazen) ${ }^{\mathrm{e}}$ & 116 & 27,91 & 8,994 & & & \\
\hline & Yılda 19 gün ve aşağısı(nadiren) $)^{\mathrm{f}}$ & 154 & 27.64 & 8.043 & & & \\
\hline \multirow{6}{*}{$\begin{array}{l}\text { DOSPERT } \\
\text { Toplam }\end{array}$} & Yılda 100 gün ve üzeri (aşırı sık) ${ }^{a}$ & 112 & 92.63 & 23.429 & \multirow{6}{*}{1.24} & \multirow{6}{*}{0.28} & \\
\hline & Yılda 80-99 gün arası (çok sık) ${ }^{b}$ & 54 & 93.15 & 22.972 & & & \\
\hline & Y1lda 60-79 gün arası (sık s1k) ${ }^{c}$ & 76 & 86.13 & 22.012 & & & \\
\hline & Y1lda 40-59 gün arası (s1k) ${ }^{d}$ & 140 & 90.84 & 22.275 & & & \\
\hline & Y1lda 20-39 gün arası (bazen) ${ }^{\mathrm{e}}$ & 116 & 89.72 & 21.997 & & & \\
\hline & Y1lda 19 gün ve aşağısı(nadiren) ${ }^{\mathrm{f}}$ & 154 & 88.46 & 18.735 & & & \\
\hline
\end{tabular}

Tablo 9'da görülebileceği gibi araştırmada yer alan macera rekreasyonu katılımcılarının etkinliğin gerçekleştirilme sıklığ değişkenine göre risk alma davranışı arasında istatistiksel olarak bir farklılaşma olup olmadığını anlamak için yapılan tek yönlü varyans analizi (ANOVA) sonucunda etkinliğe katılım sıklığ 1 değişkenine göre DOSPERT toplam puanları ve alt boyutları arasında istatistiksel olarak anlamlı farklılıklar görülmemiştir.(F=1.44 (E); $1.00(\mathrm{~S} / \mathrm{G}) ; 1.48(\mathrm{~F}) ; 0.53(\mathrm{~S}) ; 1.94(\mathrm{R}) ; 1.24(\mathrm{DT}), \mathrm{P}>.05)$.

Tablo 10. Katılımcıların Risk Alma Davranış Puanlarının Etkinliğin Gerçekleştirilme Süresi Değişkeni Bakımından Karşılaştırılması (ANOVA Sonuçları)

\begin{tabular}{|c|c|c|c|c|c|c|c|}
\hline & ETKİNLİK SÜRESİ & $\mathbf{N}$ & $\begin{array}{c}\text { Ortalama } \\
\overline{\mathbf{x}} \\
\end{array}$ & $\mathbf{S S}(\sigma)$ & $\mathbf{F}$ & $\mathbf{P}$ & $\begin{array}{c}\text { Gruplar Arası } \\
\text { Farklar }\end{array}$ \\
\hline \multirow[t]{4}{*}{ Etik } & Günübirlik $^{\text {a }}$ & 240 & 5.76 & 3.38 & \multirow{4}{*}{1.74} & \multirow{4}{*}{0.15} & \multirow{4}{*}{---------- } \\
\hline & Günaşırı (birkaç gün) ${ }^{b}$ & 242 & 6.19 & 3.10 & & & \\
\hline & Haftalık $^{\mathrm{c}}$ & 101 & 5.49 & 2.72 & & & \\
\hline & Ekspedisyon (haftadan daha uzun) $^{\mathrm{d}}$ & 69 & 6.29 & 2.87 & & & \\
\hline Sağlık/ & Günübirlik $^{\mathrm{a}}$ & 240 & 15.42 & 6.50 & \multirow{4}{*}{1.99} & \multirow{4}{*}{0.11} & \multirow{4}{*}{---------- } \\
\hline \multirow[t]{3}{*}{ Güvenlik } & Günaşırı (birkaç gün) ${ }^{b}$ & 242 & 15.97 & 6.22 & & & \\
\hline & Haftalık $^{\mathrm{c}}$ & 101 & 15.20 & 6.41 & & & \\
\hline & Ekspedisyon (haftadan daha uzun) $^{\mathrm{d}}$ & 69 & 17.38 & 7.22 & & & \\
\hline \multirow[t]{4}{*}{ Finans } & Günübirlik $^{\mathrm{a}}$ & 240 & 11.15 & 5.23 & \multirow{4}{*}{0.98} & \multirow{4}{*}{0.40} & \\
\hline & Günaşırı (birkaç gün) ${ }^{b}$ & 242 & 11.98 & 6.37 & & & \\
\hline & Haftalık $^{\mathrm{c}}$ & 101 & 11.31 & 4.96 & & & \\
\hline & 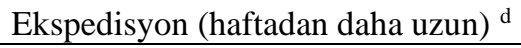 & 69 & 11.83 & 5.27 & & & \\
\hline \multirow[t]{4}{*}{ Sosyal } & Günübirlik $^{\mathrm{a}}$ & 240 & 27.92 & 6.39 & \multirow{4}{*}{0.07} & \multirow{4}{*}{0.97} & \\
\hline & Günaşırı (birkaç gün) ${ }^{b}$ & 242 & 28.15 & 6.60 & & & \\
\hline & Haftalık $^{\mathrm{c}}$ & 101 & 28.22 & 6.62 & & & \\
\hline & Ekspedisyon (haftadan daha uzun) ${ }^{\mathrm{d}}$ & 69 & 28.01 & 6.15 & & & \\
\hline \multirow[t]{4}{*}{ Rekreasyon } & Günübirlik $^{\mathrm{a}}$ & 240 & 27.62 & 9.19 & \multirow{4}{*}{1.97} & \multirow{4}{*}{0.11} & \\
\hline & Günaşırı (birkaç gün) ${ }^{b}$ & 242 & 29.48 & 8.27 & & & \\
\hline & Haftalık $^{\mathrm{c}}$ & 101 & 29.26 & 9.28 & & & \\
\hline & Ekspedisyon (haftadan daha uzun) ${ }^{\mathrm{d}}$ & 69 & 28.72 & 8.52 & & & \\
\hline DOSPERT & Günübirlik $^{\mathrm{a}}$ & 240 & 87.87 & 5.23 & \multirow{4}{*}{0.60} & \multirow{4}{*}{0.60} & \multirow{4}{*}{----------- } \\
\hline \multirow[t]{3}{*}{ Toplam } & Günaşırı (birkaç gün) ${ }^{b}$ & 242 & 91.77 & 6.37 & & & \\
\hline & Haftalık $^{\mathrm{c}}$ & 101 & 89.47 & 4.96 & & & \\
\hline & Ekspedisyon (haftadan daha uzun) ${ }^{\mathrm{d}}$ & 69 & 92.23 & 5.27 & & & \\
\hline
\end{tabular}

Tablo 10'da görülebileceği gibi araştırmada yer alan macera rekreasyonu katılımcılarının etkinliğin gerçekleştirilme süresi değişkenine göre risk alma davranışı arasında istatistiksel olarak bir farklılaşma 
olup olmadığını anlamak için yapılan tek yönlü varyans analizi (ANOVA) sonucunda etkinliğin gerçekleştirilme süresi değişkenine göre DOSPERT ölçeği toplam puanları ve alt boyutları arasında istatistiksel olarak anlamlı farklılıklar görülmemiştir (F=1.74 (E); $1.99(\mathrm{~S} / \mathrm{G}) ; 0.98(\mathrm{~F}) ; 0.07$ (S); 1.97 (R); 0.60 (DT). P>.05).

Tablo 11. Katılımcıların Risk Alma Davranış Puanlarının Etkinliğin Gerçekleştirilmesinde Bağlı Olunan Kurum/Kuruluş Değişkeni Bakımından Karşılaştırılması (ANOVA ve Posthoc Analiz Sonuçları)

\begin{tabular}{|c|c|c|c|c|c|c|c|}
\hline & Kurum/Kuruluş & $\mathbf{N}$ & $\begin{array}{c}\text { Ortalama } \\
\overline{\mathbf{x}}\end{array}$ & $\mathbf{S S}(\sigma)$ & $\mathbf{F}$ & $\mathbf{P}$ & $\begin{array}{c}\text { Gruplar Arası } \\
\text { Farklar }\end{array}$ \\
\hline \multirow[t]{5}{*}{ Etik } & Bireysel $^{a}$ & 242 & 6.10 & 3.24 & \multirow{5}{*}{1.32} & \multirow{5}{*}{0.26} & \multirow{5}{*}{---------- } \\
\hline & Kulüp/Dernek ${ }^{\text {b }}$ & 299 & 5.79 & 3.07 & & & \\
\hline & Üniversite topluluğu ${ }^{c}$ & 75 & 6.35 & 3.32 & & & \\
\hline & Üniversite seçmeli/zorunlu ders ${ }^{\mathrm{d}}$ & 16 & 4.75 & 2.56 & & & \\
\hline & İlgili spor federasyonu sporcusu ${ }^{\mathrm{e}}$ & 20 & 5.50 & 2.30 & & & \\
\hline Sağlık & Bireysel $^{\mathrm{a}}$ & 299 & 16.62 & 6.77 & \multirow{5}{*}{2.32} & \multirow{5}{*}{0.05} & \\
\hline \multirow[t]{4}{*}{ /Güvenlik } & Kulüp/Dernek ${ }^{\text {b }}$ & 75 & 15.25 & 6.44 & & & \\
\hline & Üniversite topluluğu ${ }^{c}$ & 16 & 15.92 & 5.50 & & & \\
\hline & Üniversite seçmeli/zorunlu ders ${ }^{\mathrm{d}}$ & 20 & 16.19 & 6.32 & & & \\
\hline & İlgili spor federasyonu sporcusu ${ }^{\mathrm{e}}$ & 242 & 13.25 & 6.07 & & & \\
\hline \multirow[t]{5}{*}{ Finans } & Bireysel $^{\mathrm{a}}$ & 75 & 11.48 & 5.72 & \multirow{5}{*}{1.01} & \multirow{5}{*}{0.40} & \multirow{5}{*}{--------- } \\
\hline & Kulüp/Dernek ${ }^{\text {b }}$ & 16 & 11.60 & 5.52 & & & \\
\hline & Üniversite topluluğu ${ }^{c}$ & 20 & 12.33 & 6.25 & & & \\
\hline & Üniversite seçmeli/zorunlu ders ${ }^{\mathrm{d}}$ & 242 & 9.94 & 5.33 & & & \\
\hline & İlgili spor federasyonu sporcusu ${ }^{\mathrm{e}}$ & 299 & 10.15 & 4.17 & & & \\
\hline \multirow[t]{5}{*}{ Sosyal } & Bireysel $^{\mathrm{a}}$ & 16 & 29.22 & 6.60 & \multirow{5}{*}{3.65} & \multirow{5}{*}{$0.00 * *$} & \multirow{5}{*}{$a-b$} \\
\hline & Kulüp/Dernek ${ }^{\text {b }}$ & 20 & 27.27 & 6.43 & & & \\
\hline & $\ddot{U ̈ n i v e r s i t e ~ t o p l u l u g ̆ u ~}^{\mathrm{c}}$ & 242 & 27.49 & 5.64 & & & \\
\hline & Üniversite seçmeli/zorunlu ders ${ }^{\mathrm{d}}$ & 299 & 29.50 & 7.64 & & & \\
\hline & İlgili spor federasyonu sporcusu ${ }^{\mathrm{e}}$ & 75 & 26.85 & 5.55 & & & \\
\hline \multirow[t]{5}{*}{ Rekreasyon } & Bireysel $^{\mathrm{a}}$ & 20 & 29.43 & 8.54 & \multirow{5}{*}{1.52} & \multirow{5}{*}{0.19} & \multirow{5}{*}{---------- } \\
\hline & Kulüp/Dernek ${ }^{\text {b }}$ & 242 & 27.90 & 9.17 & & & \\
\hline & $\ddot{U ̈ n i v e r s i t e ~ t o p l u l u g ̆ u ~}^{\mathrm{c}}$ & 299 & 29.65 & 7.96 & & & \\
\hline & Üniversite seçmeli/zorunlu ders ${ }^{\mathrm{d}}$ & 75 & 29.75 & 8.27 & & & \\
\hline & İlgili spor federasyonu sporcusu ${ }^{\mathrm{e}}$ & 16 & 26.85 & 9.82 & & & \\
\hline DOSPERT & Bireysel $^{\mathrm{a}}$ & 242 & 92.85 & 21.56 & \multirow{5}{*}{2.53} & \multirow{5}{*}{$0.03 *$} & \multirow{5}{*}{$\begin{array}{l}a-b \\
a-e\end{array}$} \\
\hline \multirow[t]{4}{*}{ Toplam } & Kulüp/Dernek ${ }^{\mathrm{b}}$ & 299 & 87.80 & 22.23 & & & \\
\hline & $\ddot{U ̈ n i v e r s i t e ~ t o p l u l u g ̆ u ~}^{\mathrm{c}}$ & 75 & 91.75 & 19.69 & & & \\
\hline & Üniversite seçmeli/zorunlu ders ${ }^{\mathrm{d}}$ & 16 & 90.13 & 18.91 & & & \\
\hline & İlgili spor federasyonu sporcusu ${ }^{\mathrm{e}}$ & 20 & 82.60 & 20.90 & & & \\
\hline
\end{tabular}

Tablo 11'de görülebileceği gibi araştırmada yer alan macera rekreasyonu katılımcılarının etkinliğin gerçekleştirilmesinde bağlı olunan kurum/kuruluşa göre risk alma davranış düzeyleri arasında istatistiksel olarak bir farklılaşma olup olmadığını anlamak için yapılan tek yönlü varyans analizi (ANOVA) sonucunda "DOSPERT" ölçeğine ait toplam puan ve "sosyal" alt boyut arasında anlamlı farkl11kklar bulunmuştur ( $\mathrm{F}=(\mathrm{DT}) ; 2.53(\mathrm{~S}) ; 3.65, \mathrm{p}<.05)$. Bağlı olunan kurum/kuruluşa yönelik farklılıkların hangi gruplar arasında olduğunu belirlemek amacıyla posthoc analizlerinden varyansların homojen olduğu durumlarda seçilebilecek "Scheffe/karşılaştırılacak grup sayısının çok olduğu durumda, gruplardaki gözlem sayısını dikkate almaz" test sonuçlarına bakılmıştır. Buna göre DOSPERT toplam puan açısından bireysel katılımcilar $(\overline{\mathbf{x}}=92.85)$ ile kulüp/dernek $(\overline{\mathbf{x}}=87.80)$ ve ilgili spor federasyonu sporcuları (82.60) arasında anlamlı farklılıklar bulunmuştur. "Sosyal" alt boyutunda ilişkin bireysel katılımcılar $(\overline{\mathbf{x}}=29.22)$ ile kulüp/dernek $(\overline{\mathbf{x}}=27.27)$ aracılığıyla macera rekreasyonu etkinliklerine katılım gösteren katılımcılar açısından farklılaştığı görülmektedir.

\section{TARTIŞMA}

Macera rekreasyonu katılımcılarının risk alma davranış düzeylerinin bazı demografik değişkenlere göre incelendiği araştırmada gerçekleştirilen analiz sonuçları değerlendirildiğinde; risk alma davranış düzeyleri ile cinsiyet arasındaki farklılaşmaya ilişkin; erkeklerin kadınlara göre etik, sağlık/güvenlik, rekreasyon ve genel olarak risk alma eğilimlerinin daha fazla olduğu görülmektedir. Elde edilen 
sonuçlar literatürde risk alma davranışı ile ilgili çalışmalarla tutarlılık göstermektedir (Arnet, 1992; Arnett ve Balle-Jense, 1993; Greene, Krcmar, Walters, Rubin, Hale, 2000; Y1lmaz, 2000). Risk alma davranış düzeyleri ile yaş grupları bakımından istatistiksel olarak anlamlı bir fark bulunmaması yaşa göre risk alma davranış düzeylerinin değişmediği söylenebilir. Schrader ve Wann (1999) yaş ortalaması 21.8 olan 87 erkek ve 82 kadın ile yaptıkları çalışmada özellikle genç ve erkek katılımcıların yüksek risk içerikli etkinliklere katıldıkları bildirilmiştir. Genel itibariyle genç katılımcıların daha fazla risk alma eğilimi gösterdiği çalışmalardan farklılaşan araştırma sonucumuzun Melo ve Gomes (2017) tarafından ifade edildiği biçimde, günümüzdeki katılımcı profilinin demografik bir değişim göstererek (Brymer ve Schweitzer 2017a), her yaş ve cinsiyetten, geniş ilgi ve deneyim yelpazesine sahip olan nüfusu kendine çeken karlı bir pazar halini alması durumuyla ilgili olabileceği düşünülmektedir.

Risk alma davranış düzeyleri ile eğitim durumları arasındaki farklılaşma değerlendirildiğinde; lisans düzeyindeki katılımcıların lisansüstü düzeydeki katılımcılara göre "sağlık/güvenlik" açısından daha fazla risk alma davranışı gösterdikleri görülürken; lisansüstü katılımcıların daha temkinli davranarak ve risk alma davranışından kaçındıkları söylenebilir. Risk alma davranış düzeyleri ile etkinlik tercihleri bakımından farklılıklar değerlendirildiğinde; doğa yürüyüşü ve kampçıllğı ile ilgilenen katılımcılar dağcılık, sportif tırmanış, rüzgar sörfü, yamaç paraşütü, yelken kanat, serbest paraşüt, rafting-kano, aletli ve derin dalış, dağ bisikleti ile ilgilenen katılımcılara göre daha az "etik" açısından risk aldıkları görülmektedir. Ayrıca kayak (herhangi bir içeriği) ile ilgilenen katılımcılar ile dağcılık, dağ bisikleti, yelken kanat, rüzgar sörfü ile ilgilenen katılımcılara göre genel risk alma davranış eğilimlerinin düşük olduğu söylenebilir. "sağlı/güvenlik" açısından doğa yürüyüşü ve kampçılığı ile ilgilenen katılımcılar yelken kanat ve rafting-kano ile ilgilenen katılımcılara gör daha az risk alma davranışı göstermektedir. Bu durum değerlendirildiğinde en fazla sağlık/güvenlik açısından risk alma davranışı gösteren grup yelken kanat katılımcıları ve ardından rüzgar sörfü katılımcıları gelmektedir. "sosyal" açıdan risk alma davranış düzeyleri değerlendirildiğinde en fazla sosyal risk alan grup serbest paraşüt ile ilgilenen katılımcılar olurken; en az sosyal risk alan doğa yürüyüşü ve kampçılığı ile ilgileneler gelmektedir. "Rekreasyonel" risk açısından doğa yürüyüşü ve kampçılığı ile ilgilenen katılımcıların dağcılık, rüzgar sörfü, yamaç paraşütü, yelken kanat, serbest paraşüt, rafting-kano, dağ bisikleti ile ilgilenen katılımcılara göre daha az rekreasyonel risk alma davranış eğilimi göstermektedir. Ayrıca aletli ve derin dalış ile ilgilenen katılımcılar dağcılık, yamaç paraşütü, yelken kanat, serbest paraşüt, rafting-kano ile ilgilenen katılımcılara göre daha az rekreasyonel risk alma davranışı gösterirler. $\mathrm{Bu}$ durum değerlendirildiğinde rekreasyonel olarak en az risk alma davranışı gösteren gruplar sırası ile aletli ve derin dalış, doğa yürüyüşü ve kampçılığı, kite sörf, kayak (herhangi bir içeriği), dağcılık, yamaç paraşütü, spor tırmanış, rafting-kano, dağ bisikleti, yelken kanat, rüzgar sörfü ve serbest paraşüt olarak değişmektedir. Sıralamaya bakıldığında en fazla rekreasyonel risk alma davranışı gösteren grubun "serbest paraşüt" ve sonra "rüzgar sörfü, yelken kanat" olduğu dikkat çekmektedir. Katılımcıların DOSPERT ölçeğine ilişkin toplam risk alma davranış eğilimleri incelendiğinde en fazla risk alma davranış eğiliminde olan grubun serbest paraşüt katılımcıları olduğu ve bu sırayı rüzgar sörfü ve yelken kanat katılımcılarının izlediği görülmektedir. En az risk alma davranış eğilimi ise doğa yürüyüşü ve kampçılığı ile ilgilenen katılımcılar gösterirken bu sırayı kite sörf, kayak (herhangi bir içeriği) ve aletli ve derin dalış ile ilgilenen katılımcılar izlemektedir. Literatürde Pedersen (1977) yılında psikoloji bölümü öğrencileri ile yaptığı çalışmada yüksek risk algısına göre sırası ile paraşütle atlama (sky diving), uçurumdan atlama (cliff jumping), yelken kanat (hang gliding), motosiklet yarışını en riskli sporlar olarak görürken en düşük riskin sualtı dalışında olduğunu bildirilmiştir. Demirhan (2003) yaptığ1 çalışmada en riskli sporların sırası ile yüksek dağ tırmanışı, kaya tırmanışı, tur kayağı, snowboard, kuzey kayağı ve alp kayağı olduğunu bildirmiştir. Risk alma davranış düzeyleri ile etkinliğe ilişkin deneyim süreleri bakımından farklılıklar değerlendirildiğinde; 26 ve/veya daha fazla deneyime sahip katılımcılar 5 ve/veya daha az yıl ve 6 ve 15 yıl arası deneyime sahip katılımcılara göre "sağlık/güvenlik" açısından daha az risk alma davranışı gösterdikleri bulunurken; en fazla risk alanlar 5 ve/veya daha az yıl deneyime sahip katılımcılar olarak belirlenmiş̧ir. Bu durumda etkinliğe ilişkin deneyim arttıkça sağlık/güvenlik açısından alınan risk alma davranışı da azalmaktadır. Bu durum deneyimli doğa ve macera sporları tutkunlarının etkinliklerdeki ölüm ve sakatlanma dahil tüm risklerin farkında olduğu ve üstesinden gelinemeyecek düzeyde risk almak yerine, riskleri en aza indirmek amacıyla yoğun eğitim veya pratik yaparak deneyimlerini arttırmakta olduğu biçimindeki Mei-Dan ve Carmont (2013) açıklamasıyla örtüşmektedir. İzleyicilerin ise katılımcıların sahip olduğu bilgi ve deneyimden yoksun olarak yapılan eylemi çok yüksek olarak algılamaları ve deneyimsiz katılımcıların daha yüksek düzeyde kazaya maruz kalmaları bu sonucu yaratan temel etken olarak değerlendirilebilir. 
Araştırma sonuçlarımız 1şığında risk alma davranış düzeyi etkinliğin gerçekleştirilme sıklığ ve süresinden bağımsızdır. Risk alma davranış düzeyi ile etkinliğin gerçekleştirilmesinde bağlı olunan kurum ve kuruluşa göre etkinliğe bireysel katılım gösteren katılımcilar etkinliğe kulüp ve dernek aracılığı ile katılım gösterenlere göre daha fazla sosyal risk almaktadırlar. Herşeyden önce macera bireysel tercihtir (Priest ve Gass, 2017). Hiç kimsenin risk alma yönünde zorlanamayacağını savunan yazarlar bunu bireyin ruh halini yansıtan bir deneyim olarak açıklamaktadırlar. Bireysel katılımcılar etkinliği tamamen oto kontrollerinin altında tutmaktadır. Başkalarının sorumluluğu ve onlar adına yönetilmesi gereken bir risk üstlenmedikleri için daha yüksek risk almayı tercih etmeleri yaygın görülen bir durumdur (Dinç, 2018). Etkinlikte grup sorumluluğunu almayı gerektiren durumlardan bağımsız oldukları için riski kendi beceri ve deneyimleriyle karşılayabileceklerini düşünmektedirler. Gerçekten de doğa ve macera rekreasyonu etkinlikleri her bir katılımcıya farklı hedeflerini gerçekleştirebilecekleri deneyim firsatı sağlamakta ve doğal alanlarla ilgili özel bilgi, beceri ve yetenekler geliştirmektedir. Grup halinde etkinliklere katılanlar ve liderlik yapanlar sosyal etkileşim ve karşılıklı bağımlılık hissettiren firsatlar, geliştirmektedir (D'Amato \& Krasny, 2011; Ewert \& Sibthorp, 2014). Bu durum bireysel meydan okuma (mücadele) düzeyini geri plana alarak grupla daha güvenli hareket etmeyi zorunlu kılıyor gibi görünmektedir. Dolayısıyla bireysel katılımcılar sosyal risk alma davranış eğiliminde olmaktan kaçınarak yüksek heyecan arayışı, risk ve mücadele duygusuna yöneliyor olabilir.

\section{SONUÇ ve ÖNERILER}

Sonuç olarak; cinsiyet, eğitim durumu, etkinlik tercihi, etkinlik deneyimi, etkinliğin gerçekleştirilmesinde bağlı olunan kurum ve kuruluş demografik değişkenlerine göre macera rekreasyonu katılımcılarının risk alma davranış düzeyleri açısından farklılıkların olduğu tespit edilmiştir. Bu farklılıklar; erkek katılımcıların kadın katılımcılara göre DOSPERT ölçeğinin etik, sağlık/güvenlik, rekreasyonel alt boyutlarına ilişkin risklere daha açık oldukları, daha fazla risk alma eğiliminde oldukları belirlenmiştir. Lisans düzeyindeki katılımcıların lisansüstü düzeydeki katılımcılara göre daha fazla sağlı/güvenlik yönünde risk alma eğiliminde oldukları tespit edilirken lisansüstü katılımcılar bu risk grubuyla ilgili daha temkinli davrandıkları sonucuna varılmıştır. Sağlik/güvenlik risk grubunda en fazla risk alanların yelken kanat sporuyla ilgilen katılımcıların olduğu görülürken bu sıray1 rüzgar sörfüyle ilgilenen katılımcılar izlemektedir. Sosyal risk boyutunda en fazla riski serbest paraşütle ilgilenen katılımcılar alırken; en az riski doğa yürüyüşü ve kampçılığı ile ilgilenen katılımcılar almaktadır. Rekreasyonel risk grubunda en fazla risk alma eğilimi gösterenler yüksek risk alma seviyesine göre serbest paraşüt, rüzgar sörfü ve yelken kanat katılımcıları oluştururken; en az risk alanlar aletli ve/veya derin dalış, doğa yürüyüşü ve kampçılığı ile kite sörf ile ilgilenen katılımcılar oluşturmaktadır. Sağlık/güvenlik açısından en fazla risk alanların en az (5 ve/veya daha az) deneyime sahip olan katılımcıların oluşturduğu belirlenmiştir. Bireysel olarak etkinliklere katılım gösterenlerin ise en fazla sosyal risk alma eğiliminde oldukları belirlenmiştir. Araştırmada ele alınan cinsiyet, eğitim durumu, etkinlik tercihi, etkinlik deneyimi, etkinliğin gerçekleştirilmesinde bağlı olunan kurum ve kuruluş gibi demografik değişkenler ile gerçekleştirilen analizler sonuçları ile literatürde yer alan çalışmaların bazılarında farklılık olsa da genel olarak sonuçların tutarlı olduğu söylenebilir. Bu noktada ileride yapılacak çalışmalara yönelik olarak şu önerilerde bulunulabilir.

- Farklı risk düzeyindeki macera rekreasyonu etkinlikleri (kolay macera-zor macera vb.) ele alınarak demografik değişkenlere ilişkin çalışmaların çoğaltılması,

- Kişilik profilleri ve risk alma düzeyleri ilişkilerinin incelenmesi,

- Risk alma düzeyi ardında yatan sosyal faktörlerin ortaya konması,

- Liderlik özelliklerinin ve grup liderliğilerinin risk alma davranış tercihlerinin incelenmesi,

- Güncel macera literatüründe ele alındığı biçimde macera katılımı sonucunda ortaya çıkan bireysel iyi olma hali düzeyi üzerinde risk alma davranışının yordayıcı etkisi,

- Macera spor katılımında karşılaş1lan durumlara özel davranış örüntülerinin ortaya konduğu risk alma ölçeği geliştirme araştırmaları gerçekleştirilebilir.

\section{KAYNAKLAR}

Ardahan, F. (2012). Duygusal Zekâ ve Yaşam Doyumu Arasındaki İlişkinin Doğa Sporu Yapanlar Örneğinde İncelenmesi Pamukkale Journal of Sport Sciences Vol.3, No.3, Pg:20-33. 
Arnett, J. (1992). Socialization and adolescent reckless behavior: A reply to Jessor. Developmental Review. 12: 391-409.

Arnett, J., Balle-Jense, L. (1993). Cultural bases of risk behavior: Danish adolescents. Child Development. 64: 1842-1855.

Brymer, E., \& Oades, L. (2009). Extreme Sports: A Positive Transformation in Courage and Humility. Journal of Humanistic Psychology 49(1),, 114-126.

Brymer, E., \& Schweitzer, R. (2017a). Phenomenology and the Extreme Sport Experience. London: Routledge.

Brymer, E. \&. Schweitzer. R. D (2017b). "Evoking the Ineffable: The Phenomenology of Extreme Sports" Psychology of Consciousness: Theory, Research, and Practice 4 (1): 63-74.

Büyüköztürk, Ş. (2011). Sosyal Bilimler için Veri Analizi El Kitabı: İstatistik, Araştırma Deseni, SPSS Uygulamaları ve Yorum. (ss.181). Ankara: Pegem Yayınevi.

Blais, AR, Weber, EU. (2002). Testing invariance in risk taking: a comparison between anglophone and francophone groups, Scientific Series, 25, 1-28.

Blais, A. R. \& Weber. E. U. (2006). A Domain-specific Risk-taking (DOSPERT) Scale for Adult Populations. Judgment and Decision Making, (1) 33-47.

Castanier, C., Scanff, C., \& Woodman, T. (2010). Who Takes Risks in High-Risk Sports? A Typological Personality Approach. Research Quarterly for Exercise and Sport Physical Education, Recreation and Dance Vol. 81, No. 4,, 478-484.

Demirhan, G. (2003). Dağ Sporlarına İlişkin Riskin algılanması. Gazi Beden Eđitimi ve Spor Bilimleri Dergisi (Gazi BESBD), VIII (2003). (3): 3-10

Demirhan, G. (2005). Mountaineers Risk Perception in Outdoor-Adventure Sports A Study of Sex and Sports Experience, J. Of Perceptual and Motor Skills.

Demirhan G., Aşçı H.F., Kangalgil, M., Saraçbaşı M.O. (2014). Extrem sporları risk algısı ve çekicilik ölçeği. Hacettepe Spor Bilimleri Dergisi, 25(1), 11-22.

Dickson, T., Dolnicor, S. (2004). No Risk, No Fun: The Role of Perceived Risk in Adventure Tourism. University Of Wollongong. Research Online. Web: 1-11.

Dinç, S. C., Koca, C., Demirhan, G., \& Aşc1, H. (2004). An Investıgatıon of Rısk Participation and Risk Views of Male and Female University Students Before and After Participating the Outdoor Activities Experience. The 10th Ichper. SD Europe Congress.

Dinç, S.C. (2018). Doğa Sporları Etkinliklerine İlişkin Liderlik Ölçeğinin Geliştirilmesi. Spor Yayınevi ve Kitapevi Ankara.

Dinç, S. C., Saçlı Uzunöz, F. ve Güneş, B. (2018). Risk Alma ve Eleştirel Düşünme Eğilimlerinde Doğa Macera Eğitimine Bağlı Değişimlerin İncelenmesi, Ahi Evran Üniversitesi Sosyal Bilimler Enstitüsü Dergisi, 4(2), 166-182.

Dinç, S.C. ve Yavaş Tez, Ö. (2019-a). Investigation of the Relationship Between the Dominant Brain Areas, Risk-Taking and Alexithymia of Outdoor Adventure Recreation Participants. Journal of Education and Learning, 8(3) doi.org/10.5539/jel.v8n3p44.

Dinç, S.C. ve Yavaş Tez, Ö. (2019-b). Alana Özgü Risk Alma Ölçeği- Kısa Formu'nun (DOSPERT30) Türkçe Uyarlaması, Spor Bilimleri Dergisi 30 (3), 107-120 DOI: doi.org/10.17644/sbd.471304

D'Amato, L.G. \& Krasny M. E. (2011). Outdoor Adventure Education: Applying Transformative Learning Theory to Understanding Instrumental Learning and Personal Growth in Environmental Education. The Journal of Environmental Education, pp. 237-254.

Ewert, A.W. \& Hollenhorst, S. (1995). Adventure Recreation and Its Implication for Wilderness. International Journal of Wilderness. 3(2):1-21

Ewert, A.W. \& Sibthorp, J. (2014) Outdoor Adventure Education: Foundation, Theory, and Research; Human Kinetics, Champaign IL.

Greene, K., Krcma, M., Walters, L.H., Rubin, D.L., Hale, L. (2000). Targeting adolescent risk-taking behaviors: the contributions of egocentrism and sensation-seeking. Journal of Adolescence. (23): 439-461.

Guszkowska, M., Boldak, A. (2010). Sensation Seeking in Males Involved in Recreation. High Risk Sports. Biology Sport. 27(3): 157- 162.

Gomes, R., N. Gustavo, R. Melo, and V. Pedragosa. (2017). Private Sport Sector in Europe - A CrossNational Perspective, edited by A. Laine, and H. Vehmas, 269-285. Cham: Springer. 
Howard, R.A. (2009). A Case Study of The Ottowa Valley Whitewater Rafting Industry: Standards and Risk Mangement. Brock Universiy. Submitted In Partial Fulfillment of The Requirements Forth He Degree of Master of Arts in Appired Health Sciences.pp: 10-20.

Houge Mackenzie, S., \& Hodge, K. (2019). Adventure recreation and subjective well-being: a conceptual framework,. Leisure Studies, , 1-15. DOI:10.1080/02614367.2019.1577478.

Llewellyn, D., \& Sanchez, X. (2008). Individual differences and risk taking in rock climbing. Psychology of Sport and Exercise, 9, , 413-426.

Mazıcıŏlu, M. M., Baştürk, M. \& Çetinkaya, M. (2000). Dağcılarda Kişilik Yapısının Araştırılması: Kisa Semptom Envanteri, Klinik Psikiyatri 3: 61-66.

Melo, R. \& R. Gomes. (2017). "Nature Sports Participation: Understanding Demand, Practice Profile, Motivations and Constraints." European Journal of Tourism Research 16: 108-135.

Mei-Dan, O. \& Carmont, M. R. (2013) Adventure and Extreme Sports Injuries: Epidemiology, Treatment, Rehabilitation and Prevention. Springer-Verlag: London.

Melo, R., Van Rheenen, D. \& Gammon S. J. (2020) Part II: Nature Sports: Current Trends and The Path Ahead, Annals of Leisure Research, 23:2, 133-142, DOI:10.1080/11745398.2019.1672310

Mishra, S. \& Lalumiére, M.L. (2010). You Can't Always Get What You Want: The Motivationel Effect ofNeed on Risk-Sensitive-Decission-Making, Journal of Experiment Al Social Psychology. (46): 605-611.

Monasterio E. (2012). Mental Characteristics of Extreme Sports Athletes. In: Mei-Dan O, Carmont MR, (eds). Adventure and extreme sports injuries: London: Springer.

Muszkieta R. \& Gembiak M. (2004) Uwarunkowania i motywy uprawiania sportów ekstremalnych. In: Z. Dziubiński (ed.) Edukacja poprzez sport. Salezjańska Organizacji Sportowa RP, Warszawa. pp: 478.

Pedersen, M. D. (1997). Perceptions of High-Risk Sport. Perceptual and Motor Skills. (85): 756-758.

Priest, S. \& Gass, M. (2017) Effective Leadership in Adventure Programming, 3E. USA: Human Kinetics

Rajola, E., \& O'Keefe, M. (1999). Philosophy in practice: A history of adventure programming. In J. C. Miles \& S. Priest (Eds.), Adventure Programming (pp. 45-53). State College, PA: Venture.

Seligman, M., \& Csikszentmihalyi, M. (2014). Positive psychology: An introduction . New York: Springer Netherlands (pp. 279-298).

Schrader, M.P. \& Wann, D.L. (1999). High-risk Recreation: The Relationship Between Participant Characteristics and Degree of Involvement. Journal of Sport Behavor. 22 (3): 426-441.

Özen, G., Ölçücü, B., Özen, Ş. \& Demirel, N. (2014) Spor Eğitiminde dağ tırmanışı antrenmanı ve zirve tırmanışının öz-yeterlilik düzeyine etkisi. Uluslararası Türk Eğitim Bilimleri Dergisi Ekim, 2014: (131-136)

Virden, R. (2006). Outdoor and Adventure Recreation. H. Kinetics içinde, Introduction To Recreation and Leisure (s. 307-333). Champaign: Human Kinetics.

Weber, EU, Blais, AR, Betz, N. (2002). A Domain Specific Risk Attitude Scale: measuring risk perceptions and risk behaviors. Journal of Behaviroal Decision Making, 15, 263-290.

Wheaton, B. (2013). The Cultural Politics of Lifestyle Sports. London: Routledge.

Wheaton, B. (2016). "Lifestyle Sport." In Sport and Society: A Student Introduction, edited by B. Houlihan, and D. Malcolm, 3rd ed., 109-133. London: Sage.

Weber, E.U., Blais, A.R., Betz, N. (2002). A Domain Specific Risk Attitude Scale: Measuring Risk Perceptions and Risk Behaviors. Journal of Behaviroal Decision Making. (15): 263-290.

Yılmaz, T. (2000). Ergenlerde Risk Alma Davranışlarının İncelenmesi. (Yayımlanmamış Yüksek Lisans Tezi). İzmir: Ege Üniversitesi Sosyal Bilimler Enstitüsü.

Zuckerman, M. (1990). The psychophysiology of sensation seeking. Journal of Personality; 58, $313-$ 345 .

\section{CITATION OF THIS ARTICLE}

Dinç, C.S. \& Yavaş Tez, Ö. (2021). Macera Rekreasyonu Katılımcılarının Risk Alma Davranışlarında Farklılık Yaratan Değişkenlerin İncelenmesi. International Journal of Sport, Exercise \& Training Sciences - IJSETS, 7(4), 203-219. DOI: 10.18826/useeabd.1002314. 